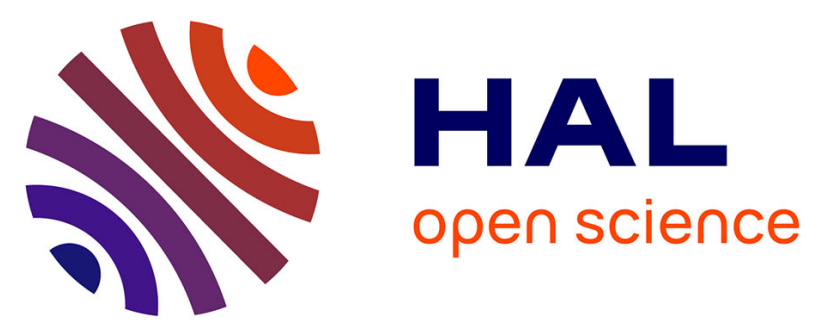

\title{
Strong regional influence of climatic forcing datasets on global crop model ensembles
}

\author{
Alex Ruane, Meridel Phillips, Christoph Müller, Joshua Elliott, Jonas \\ Jägermeyr, Almut Arneth, Juraj Balkovic, Delphine Deryng, Christian \\ Folberth, Toshichika Iizumi, et al.
}

\section{To cite this version:}

Alex Ruane, Meridel Phillips, Christoph Müller, Joshua Elliott, Jonas Jägermeyr, et al.. Strong regional influence of climatic forcing datasets on global crop model ensembles. Agricultural and Forest Meteorology, 2021, 300, pp.108313. 10.1016/j.agrformet.2020.108313 . hal-03124750

\author{
HAL Id: hal-03124750 \\ https://hal.science/hal-03124750
}

Submitted on 2 Jul 2021

HAL is a multi-disciplinary open access archive for the deposit and dissemination of scientific research documents, whether they are published or not. The documents may come from teaching and research institutions in France or abroad, or from public or private research centers.
L'archive ouverte pluridisciplinaire $\mathbf{H A L}$, est destinée au dépôt et à la diffusion de documents scientifiques de niveau recherche, publiés ou non, émanant des établissements d'enseignement et de recherche français ou étrangers, des laboratoires publics ou privés. 


\title{
Strong regional influence of climatic forcing datasets on global crop model ensembles
}

\author{
Alex C. Ruane ${ }^{\mathrm{a}, *}$, Meridel Phillips ${ }^{\mathrm{a}, \mathrm{b}}$, Christoph Müller ${ }^{\mathrm{c}}$, Joshua Elliott ${ }^{\mathrm{d}}$, Jonas Jägermeyr ${ }^{\mathrm{a}, \mathrm{d}}$, \\ Almut Arneth ${ }^{\mathrm{e}}$, Juraj Balkovic ${ }^{\mathrm{f}, \mathrm{g}}$, Delphine Deryng ${ }^{\mathrm{h}}$, Christian Folberth ${ }^{\mathrm{g}}$, Toshichika Iizumi ${ }^{\mathrm{i}}$, \\ Roberto C. Izaurralde ${ }^{j}$, Nikolay Khabarov ${ }^{w}$, Peter Lawrence ${ }^{k}$, Wenfeng Liu ${ }^{1}$, Stefan Olin ${ }^{\circ}$, \\ Thomas A.M. Pugh ${ }^{\text {o, p, }}$, Cynthia Rosenzweig ${ }^{a}$, Gen Sakurai ${ }^{\mathrm{i}}$, Erwin Schmid ${ }^{\mathrm{r}}$, Benjamin Sultan ${ }^{\mathrm{s}}$, \\ Xuhui Wang ${ }^{\mathrm{m}, \mathrm{t}}$, Allard de Wit ${ }^{\mathrm{u}}$, Hong Yang ${ }^{\mathrm{n}, \mathrm{v}}$ \\ ${ }^{\text {a }}$ NASA Goddard Institute for Space Studies, New York, New York, USA \\ ${ }^{\mathrm{b}}$ Center for Climate Systems Research, Earth Instiute, Columbia University, New York, New York, USA \\ ${ }^{\mathrm{c}}$ Potsdam Institute for Climate Impact Research, Member of the Leibniz Association, Potsdam, Germany \\ ${ }^{\mathrm{d}}$ University of Chicago, Chicago, Illinois, USA \\ e Department Atmospheric Environmental Research, Karlsruhe Institute of Technology, Garmisch-Partenkirchen, Germany \\ ${ }^{\mathrm{f}}$ Department of Soil Science, Comenius University in Bratislava, Bratislava, Slovak Republic \\ ${ }^{g}$ Biodiversity and Natural Resources, International Institute for Applied Systems Analysis, Laxenburg, Austria \\ ${ }^{\mathrm{h}}$ IRI THESys, Humboldt-Universität zu Berlin, Berlin, Germany \\ ${ }^{\mathrm{i}}$ National Agriculture and Food Research Organization, Tsukuba, Ibaraki, Japan \\ ${ }^{\mathrm{j}}$ Department of Geographical Sciences, University of Maryland, College Park, MD, USA \\ ${ }^{\mathrm{k}}$ Earth System Laboratory, National Center for Atmospheric Research, Boulder, CO, USA \\ ${ }^{1}$ College of Water Resources and Civil Engineering, China Agricultural University, Beijing, China \\ ${ }^{\mathrm{m}}$ Laboratoire des Sciences du Climat et de l'Environnement, LSCE/IPSL, CEA-CNRS-UVSQ Université Paris-Saclay, Gif-sur-Yvette, France \\ ${ }^{\mathrm{n}}$ Eawag, Swiss Federal Institute of Aquatic Science and Technology, Duebendorf, Switzerland \\ ${ }^{\circ}$ Department of Physical Geography and Ecosystem Science, Lund University, Lund, Sweden \\ ${ }^{\mathrm{p}}$ School of Geography, Earth \& Environmental Science, University of Birmingham, Birmingham, United Kingdom \\ ${ }^{\mathrm{q}}$ Birmingham Institute of Forest Research, University of Birmingham, Birmingham, United Kingdom \\ ${ }^{\mathrm{r}}$ Institute for Sustainable Economic Development, University of Natural Resources and Life Sciences, Vienna, Austria \\ ${ }^{\mathrm{s}}$ ESPACE-DEV, Institute of Research for Development, Montpellier, France \\ ${ }^{\mathrm{t}}$ Sino-French Institute of Earth System Sciences, Peking University, Beijing, China \\ ${ }^{\mathrm{u}}$ Earth Observation and Environmental Informatics, Wageningen Environmental Research, Wageningen, The Netherlands \\ ${ }^{v}$ Department of Environmental Sciences, MGU, University of Basel, Basel, Switzerland \\ ${ }^{\mathrm{w}}$ Advanced Systems Analysis Program, International Institute for Applied Systems Analysis, Laxenburg, Austria
}

\section{A R T I C L E I N F O}

\section{Keywords:}

Agricultural Model Intercomparison and Improvement Project (AgMIP)

Global Gridded Crop Model Intercomparison (GGCMI)

Climatic Forcing Datasets

Climate Impacts

Agroclimate

Crop production

\begin{abstract}
A B S T R A C T
We present results from the Agricultural Model Intercomparison and Improvement Project (AgMIP) Global Gridded Crop Model Intercomparison (GGCMI) Phase I, which aligned 14 global gridded crop models (GGCMs) and 11 climatic forcing datasets (CFDs) in order to understand how the selection of climate data affects simulated historical crop productivity of maize, wheat, rice and soybean. Results show that CFDs demonstrate mean biases and differences in the probability of extreme events, with larger uncertainty around extreme precipitation and in regions where observational data for climate and crop systems are scarce. Countries where simulations correlate highly with reported FAO national production anomalies tend to have high correlations across most CFDs, whose influence we isolate using multi-GGCM ensembles for each CFD. Correlations compare favorably with the climate signal detected in other studies, although production in many countries is not primarily climate-limited (particularly for rice). Bias-adjusted CFDs most often were among the highest model-observation correlations, although all CFDs produced the highest correlation in at least one top-producing country. Analysis of larger multi-CFD-multi-GGCM ensembles (up to 91 members) shows benefits over the use of smaller subset of models in some regions and farming systems, although bigger is not always better. Our analysis suggests that global
\end{abstract}

\footnotetext{
* Corresponding author at: Alex Ruane, 2880 Broadway, New York, NY 10025, USA.

E-mail address: alexander.c.ruane@nasa.gov (A.C. Ruane).
} 
assessments should prioritize ensembles based on multiple crop models over multiple CFDs as long as a topperforming CFD is utilized for the focus region.

\section{Introduction}

Global agricultural systems are vulnerable to climate hazards including extreme events and long-term trends that alter the growth environment. Cultivar and farm management practices are often selected to produce high and stable yields within the current expected climate, but this still leads to underperforming years as well as emerging pressures for adaptation as regional climates shift under anthropogenic climate change (Lobell et al., 2011; Mbow et al., 2019; Porter et al., 2014; Rosenzweig et al., 2014). Understanding regional agricultural systems' climate hazard profile is critical to major international goals for disaster preparedness (e.g., the Sendai Framework; UNISDR, 2015), greenhouse gas mitigation (e.g., the Paris Agreement, United Nations, 2015a), and the Sustainable Development Goals (United Nations, 2015b). Planning for current and future farming systems is therefore rooted in solid analysis of crop response to recent historical climate, which then acts as a baseline for the generation of future agroclimatic scenarios to allow investigation of adaptation, mitigation, and resilience-building interventions (Antle et al., 2015; Lange, 2019a; Ruane et al., 2015b,a) As many of the world's most vulnerable agricultural regions are found in areas with incomplete or inconsistent meteorological observations, the Agricultural Model Intercomparison and Improvement Project (AgMIP ${ }^{1}$ ) has developed protocols and datasets to fill in observational gaps in order to provide a consistent climatic forcing for agricultural models across AgMIP and related simulation projects (Rosenzweig et al., 2013; Ruane et al., 2015b; Ruane et al., 2017).

In this study, we investigate the hypothesis that the selection of a climatic forcing dataset (CFD) has strong influence on the fidelity of crop models simulating regional production of maize, wheat, rice, and soy. To do this we utilize global agricultural model simulations conducted as part of the AgMIP Global Gridded Crop Model Intercomparison (GGCMI, Elliott et al., 2015; Müller et al., 2017; see Supplementary Material S1), allowing us to investigate multi-model ensembles to reduce model-specific bias. Our final analysis of simulation skill is the correlation between crop model ensembles and the time series of national level production (Fig. 6), with the preceding figures and sections providing examples and analysis approaches that help interpret differences across nations, crop systems, and crop model ensembles (further bolstered by the Supplementary Material). Influence of CFDs on production will depend on (i) the accuracy of climatic forcing datasets (CFDs) in capturing mean climate and resolving extreme events (Section 3), (ii) the ability of crop model biophysical process representations to capture important climatic responses (Section 4), and (iii) whether CFD differences align with critical crop model processes and structural differences in a manner that would lead to noticeable differences in agricultural response (Section 5). In this way we may apply the agricultural impacts lens to identify important differences in climate datasets that would otherwise be too subtle to distinguish. The structure of the GGCMI intercomparison also allows us to investigate the role of CFD selection within the context of GGCM/CFD ensembles including up to 91 members.

\footnotetext{
1 Abbreviations: AgMIP: The Agricultural Model Intercomparison and Improvement Project; CFD: Climatic Forcing Dagaset; GGCM: Global Gridded Crop Model; GGCMI: Global Gridded Crop Model Intercomparison
}

\section{Material and methods}

\subsection{Climatic forcing datasets}

Crop models typically require daily meteorological inputs including maximum and minimum temperature $\left(T_{\max }\right.$ and $\left.T_{\min }\right)$, precipitation $(P)$, and solar radiation $\left(S_{r a d}\right)$. Many crop models also require information about humidity (relative humidity, vapor pressure deficit, or dew point temperature), longwave radiation, and wind speed in order to more accurately estimate potential evapotranspiration. Some models utilize hourly information to better understand processes related to the diurnal cycle. High-quality in situ measurements remain the gold standard for model simulations, with remote sensing and retrospective analyses ('reanalyses') filling in gaps in space and time (Gelaro et al., 2017; Schollaert Uz et al., 2019). Agricultural applications benefit from the combination of best performing products (Toreti et al., 2019), although care must be taken to ensure that CFDs utilize bias adjustment techniques that maintain the statistics most relevant to crop models (Famien et al., 2018; Galmarini et al., 2019; Parkes et al., 2019). CFDs created for application across multiple scales, regions or sectors (e.g., Lange, 2019c) may face additional constraints in terms of variable and water/energy budget consistency than would be required of only a single scale and sector.

Reanalyses are numerical weather prediction models reinitialized multiple times each day using assimilation of observational data. These do not assimilate the specific variables needed for crop models, however, so variables like maximum and minimum temperature, precipitation rate, incident solar radiation, and near-surface humidity are the products of internal model processes and parameterizations. Observational datasets also have uncertainties and biases, particularly in regions where local observations are sparse, of poor quality, or difficult to access (Iizumi et al., 2014, 2017; Ruane et al., 2015b). Historical CFDs are typically generated by combining the universal coverage and physical consistency of reanalysis outputs with observational data from gridded in situ measurements and satellite remote sensing in order to create a uniform, coherent, and bias-adjusted dataset to drive impact models. The resulting CFD is a globally-coherent dataset with day-to-day sequences and variable relations from the reanalysis that have been adjusted to ensure that monthly statistics match observational products.

Table 1 provides an overview of the 11 climatic forcing datasets (CFDs) used in the GGCMI Phase 1 simulations evaluated in this study, including their underlying reanalyses, key bias-adjustment targets (in situ station and remote sensing products), and special notes on key aspects of the bias adjustment. Many of these datasets were compared against global station data by Ruane et al., 2015ba), which also includes additional distinction between bias-adjustment methods in the various products. The GRASP dataset is particularly unique in that it does not adjust biases on a monthly basis according to target observational datasets; rather, the 1961-1990 period was used to determine time-constant adjustment factors that are then applied to reanalysis data over the entire 1980-2010 period (Iizumi et al., 2014).

Several CFDs share common characteristics that allow us to isolate the ramifications of particular options in the CFD-generation process. AgMERRA and AgCFSR utilize the same bias-adjustment methods and target observational datasets but differentiate in their selection of underlying reanalysis (same monthly values but different daily sequences). AgCFSR and CFSR are driven by the same reanalysis, but CFSR does not undergo any bias adjustment (same daily sequence but different monthly values). Likewise, both WFDEIcru, and WFDEIgpcc are based on the ERA-INTERIM reanalysis, which is also included without biasadjustment (ERAI, same daily sequence but different monthly values). 
Table 1

Overview of Climatic forcing Datasets (adapted from Elliott et al., 2015). Acronyms are explained in table footnotes. All GGCMs utilize these CFDs' daily maximum and minimum temperatures, precipitation, and solar radiation, with some models additionally using wind speed, humidity, vapor pressure, and dewpoint temperature.

\begin{tabular}{|c|c|c|c|c|}
\hline Dataset & $\begin{array}{l}\text { Underlying } \\
\text { reanalysis } \\
\text { (resolution) } \\
\text { [reference] }\end{array}$ & Years & $\begin{array}{l}\text { CFD } \\
\text { native } \\
\text { resolution }\end{array}$ & $\begin{array}{l}\text { Bias-adjustment } \\
\text { notes (and key } \\
\text { reference) }\end{array}$ \\
\hline AgCFSR & $\begin{array}{l}\text { CFSR } \\
\left(\approx 0.3^{\circ}\right) \\
{[\text { Saha et al., 2010] }}\end{array}$ & $\begin{array}{l}1980- \\
2010\end{array}$ & $0.5^{\circ} / 0.25^{\circ}$ & $\begin{array}{l}\text { Monthly } \\
\text { temperature and } \\
\text { precipitation values } \\
\text { match ensemble of } \\
\text { CRUTS3.10 (Harris } \\
\text { et al., 2014), } \\
\text { GPCCv6 (Fuchs, } \\
\text { 2009; Rudolf et al., } \\
\text { 2010), and WM ( } \\
\text { Willmott and } \\
\text { Matsuura, 1995), } \\
\text { with adjustment to } \\
\text { CRUTS3.00 wet day } \\
\text { frequency and SRB } \\
\text { solar radiation ( } \\
\text { Stackhouse, Jr et al., } \\
\text { 2011). Diurnal } \\
\text { temperature range } \\
\text { matches CRU (on } \\
\text { average). Monthly } \\
\text { precipitation } \\
\text { climatology from } \\
\text { high-resolution } \\
\text { satellite products, } \\
\text { although that } \\
\text { information is lost at } \\
\text { 0.5 resolution used } \\
\text { in this study. } \\
\text { Includes vapor } \\
\text { pressure, dew point } \\
\text { temperature, and } \\
\text { relative humidity at } \\
\text { time of maximum } \\
\text { temperature (Ruane } \\
\text { et al., 2015b) }\end{array}$ \\
\hline AgMERRA & $\begin{array}{l}\text { MERRA } \\
\left(0.5^{\circ} \times 0.66^{\circ}\right) \\
\text { [(Rienecker et al., } \\
2011)]\end{array}$ & $\begin{array}{l}1980- \\
2010\end{array}$ & $0.5^{\circ} / 0.25^{\circ}$ & $\begin{array}{l}\text { Same bias- } \\
\text { adjustment targets } \\
\text { and methods as } \\
\text { AgCFSR, but diurnal } \\
\text { temperature range is } \\
\text { adjusted be } 3 / 4 \text { of the } \\
\text { distance between } \\
\text { MERRA and CRU (on } \\
\text { average) and } \\
\text { incorporates } \\
\text { precipitation } \\
\text { sequence from } \\
\text { MERRA-Land ( } \\
\text { Reichle et al., 2011) } \\
\text { dataset that utilizes } \\
\text { GPCP observations ( } \\
\text { Ruane et al., 2015b) }\end{array}$ \\
\hline CFSR & $\begin{array}{l}\text { CFSR } \\
\left(\approx 0.3^{\circ}\right) \\
{[\text { Saha et al., 2010] }}\end{array}$ & $\begin{array}{l}1979- \\
2011\end{array}$ & $0.3^{\circ}$ & $\begin{array}{l}\text { No bias-adjustment } \\
\text { from original } \\
\text { reanalysis (Saha } \\
\text { et al., 2010) }\end{array}$ \\
\hline ERAI & $\begin{array}{l}\text { ERA-Interim } \\
\left(0.75^{\circ}\right) \\
\text { [(European Centre } \\
\text { for Medium-Range } \\
\text { Weather Forecasts } \\
2009)]\end{array}$ & $\begin{array}{l}1979- \\
2019\end{array}$ & $0.75^{\circ}$ & $\begin{array}{l}\text { No bias-adjustment } \\
\text { from original } \\
\text { reanalysis (( } \\
\text { European Centre for } \\
\text { Medium-Range } \\
\text { Weather Forecasts } \\
\text { 2009)) }\end{array}$ \\
\hline GRASP & $\begin{array}{l}\text { JRA-25 }\left(1.125^{\circ}\right) \\
\text { [Onogi et al., } \\
\text { 2007] } \\
\text { \& ERA-40 }\end{array}$ & $\begin{array}{l}1961- \\
2010\end{array}$ & $1.125^{\circ}$ & $\begin{array}{l}\text { Adjusts to CRU- } \\
\text { TS3.10 for } \\
\text { temperature and } \\
\text { precipitation, }\end{array}$ \\
\hline
\end{tabular}

Table 1 (continued)

\begin{tabular}{|c|c|c|c|c|}
\hline Dataset & $\begin{array}{l}\text { Underlying } \\
\text { reanalysis } \\
\text { (resolution) } \\
\text { [reference] }\end{array}$ & Years & $\begin{array}{l}\text { CFD } \\
\text { native } \\
\text { resolution }\end{array}$ & $\begin{array}{l}\text { Bias-adjustment } \\
\text { notes (and key } \\
\text { reference) }\end{array}$ \\
\hline & $\begin{array}{l}\left(2.5^{\circ} \text { version }\right) \\
\text { [Uppala et al., } \\
2005]\end{array}$ & & & $\begin{array}{l}\text { CRUTS3.0 wet-day } \\
\text { frequency, CRU- } \\
\text { CL1.0 winds, and } \\
\text { SRB solar radiation. } \\
\text { Time-constant } \\
\text { correction factors } \\
\text { derived from 1961- } \\
1990 \text { period (Iizumi } \\
\text { et al., 2014) }\end{array}$ \\
\hline GSWP3 & $\begin{array}{l}20 \mathrm{CR}\left(2^{\circ}\right) \text { [Compo } \\
\text { et al., 2011] }\end{array}$ & $\begin{array}{l}1901- \\
2010\end{array}$ & $0.5^{\circ}$ & $\begin{array}{l}\text { Adjusts to GPCC } \\
\text { precipitation, SRB } \\
\text { solar radiation, and } \\
\text { CRU temperature ( } \\
\text { Dirmeyer et al., } \\
\text { 2006) }\end{array}$ \\
\hline PGFv2 & $\begin{array}{l}\text { NCAR Reanalysis } 1 \\
\left(2.8^{\circ}\right) \text { [Kalnay } \\
\text { et al., 1996] }\end{array}$ & $\begin{array}{l}1901- \\
2012\end{array}$ & $0.5^{\circ}$ & $\begin{array}{l}\text { Adjusts to CRU, } \\
\text { GPCP, SRB, and } \\
\text { utilizes the TRMM } \\
\text { Multi-satellite } \\
\text { Precipitation } \\
\text { Analysis (Sheffield } \\
\text { et al., 2006) }\end{array}$ \\
\hline Princeton & $\begin{array}{l}\text { NCAR Reanalysis } 1 \\
\left(2.8^{\circ}\right) \text { [Kalnay } \\
\text { et al., 1996] }\end{array}$ & $\begin{array}{l}1948- \\
2008\end{array}$ & $0.5^{\circ}$ & $\begin{array}{l}\text { Adjusts to CRU } \\
\text { TS2.0, GPCP, SRB, } \\
\text { and utilizes the } \\
\text { TRMM Multi- } \\
\text { satellite } \\
\text { Precipitation } \\
\text { Analysis (Sheffield } \\
\text { et al., 2006) }\end{array}$ \\
\hline WATCH & $\begin{array}{l}\text { ERA-40 }\left(2.5^{\circ}\right) \\
\text { [Uppala et al., } \\
2005]\end{array}$ & $\begin{array}{l}1958- \\
2001\end{array}$ & $0.5^{\circ}$ & $\begin{array}{l}\text { Adjusts to CRUTS2.1 } \\
\text { temperature and } \\
\text { GPCCv4 } \\
\text { precipitation. Also } \\
\text { known as WATCH } \\
\text { Forcing Data (WFD) } \\
\text { (Weedon et al., } \\
\text { 2011); listed as } \\
\text { element of GGCMI } \\
\text { Phase 1, but not } \\
\text { included in further } \\
\text { analysis given year } \\
2001 \text { end date. }\end{array}$ \\
\hline WFDEIcru & $\begin{array}{l}\text { ERA-Interim } \\
\left(0.75^{\circ}\right) \text { [Dee et al., } \\
2011]\end{array}$ & $\begin{array}{l}1979- \\
2012\end{array}$ & $0.5^{\circ}$ & $\begin{array}{l}\text { Monthly corrections } \\
\text { to CRU TS3.1/ } \\
\text { CRUTS3.101/ } \\
\text { CRUTS3.21; includes } \\
\text { longwave radiation ( } \\
\text { Weedon et al., 2018) }\end{array}$ \\
\hline WFDEIgpcc & $\begin{array}{l}\text { ERA-Interim } \\
\left(0.75^{\circ}\right) \text { [Dee et al., } \\
2011]\end{array}$ & $\begin{array}{l}1979- \\
2010\end{array}$ & $0.5^{\circ}$ & $\begin{array}{l}\text { Same as WFDEIcru } \\
\text { but precipitation } \\
\text { adjusted to GPCCv5/ } \\
\text { v6 (Weedon et al., } \\
2018 \text { ) }\end{array}$ \\
\hline
\end{tabular}

* All CFDs were applied on a common $0.5^{\circ}$ x $0.5^{\circ}$ grid for crop model simulations and analyses in this study; Native resolution shows highest level of distinction for CFD (AgMERRA and AgCFSR shown separately for all variables / precipitation only)

NCAR $=$ National Center for Atmospheric Research (USA)

CFSR $=$ NCAR Climate Forecast System Reanalysis (USA)

MERRA = Modern Era Retrospective-analysis for Research and Applications (USA)

JRA-25 $=$ 25-year Japanese Reanalysis (Japan)

ERA-40 = European Centre for Medium-range Weather Forecasting 40 year reanalysis (UK)

ERAI = European Centre for Medium-range Weather Forecasting Interim reanalysis (UK)

WM = Willmott and Matsuura, 1995

$\mathrm{SRB}=$ NASA/GEWEX Solar Radiation Budget (USA)

GPCP $=$ Global Precipitation Climatology Project (USA)

GPCC $=$ Global Precipitation Climatology Centre (Germany) 
CRU = Climatic Research Unit (University of East Anglia, UK)

$\mathrm{CMORPH}=$ Climate Prediction Center Morphing Product (USA)

PERSIANN = Precipitation Estimation using Remote-Sensing and Artificial Neural Networks (USA)

TRMM = National Aeronautics and Space Administration Tropical Rainfall Measurement Mission (USA)

TMPA $=$ TRMM Multi-satellite Precipitation Analysis (USA)

Additionally, WFDEIcru and WFDEIgpcc use the same bias-adjustment methods and target datasets with the exception of different monthly precipitation dataset targets (CRU or GPCC) (same daily sequences and monthly values except for monthly precipitation). WFDEIcru and WFDEIgpcc also represent an updated application of the WATCH methodology, while PFGv2 is an update to the Princeton CFD.

This study analyzes agroclimatic aspects of CFDs using methods established in (Ruane et al., 2018a) to target agricultural productivity. Seasonal climate factors are calculated according to the local major growing seasons for maize, wheat, rice, and soybean determined by GGCMI protocols for planting and average harvest dates (Elliott et al., 2015). In many cases this information is documented on a country-level, missing differences within a country that can be important to regional production.

We evaluate CFDs for the $1980-2010$ period, offering a 'current' climatology containing the 30 complete growing seasons that led to harvests from 1981-2010. This includes data from 1980 to account for regions where the growing season overlaps January $1^{\text {st }}$ such that planting in 1980 led to a harvest in 1981. Simulations were run with $\mathrm{CO}_{2}$ concentration data from Mauna Loa (Thoning et al., 1989). This period also included substantial climatic trends in many regions owing to large-scale modes of climate variability, as well as anthropogenic climate change, which required us to detrend GGCMI outputs when comparing against detrended FAO production anomalies (which were also detrended, as described in Section 2.4 below). The WATCH forcing dataset is not included in further analyses for this study given that it does not extend beyond 2001, but we do include analysis of simulations driven by the Princeton dataset up to 2008 .

\subsection{Global gridded crop models}

Crop models track daily water, carbon, and nitrogen balances in the plant and field environment progressing through developmental stages as determined by genotype parameters, field management, and climate drivers. These models have been developed using extensive observations and field and chamber trials, with many AgMIP-facilitated intercomparisons helping to elucidate strengths and weaknesses associated with various modeling approaches (Martre et al., 2015; McDermid et al., 2015; Ruane et al., 2017; Zhao et al., 2017).

The process-based crop models utilized in this study (Elliott et al., 2015; Müller et al., 2017) are configured using information about the cultivar genotype (e.g., temperature-based phenology, heat and drought resistance), soils (e.g., 1 to 2 meters of layered texture and water holding properties), farm management (e.g., tillage methods, planting and harvest dates, fertilizer and irrigation applications), and climate (as noted in previous section). Müller et al. (2019) and Supplementary Material S2 provide a more complete description of the 14 GGCMI models and 3 configuration types utilized, including 2 configurations in which growing season and fertilizer levels are harmonized for consistency. Irrigation is assumed to be unconstrained by water availability and any soil water deficit is balanced the next day without application or conveyance losses. Calibration of any model parameters was performed at the global scale, although modelers configured soils, cultivars, and management practices regionally (e.g., to match GGCMI growing season harmonization protocols). Observational production data were used by some models to calibrate mean yields, but no models incorporated information about the observed interannual anomalies in focus for this study.
The goal of this current study is to isolate the role of climatic forcing dataset and ensemble selection in GGCM historical performance, and we refer readers to (Müller et al., 2017) for a more detailed evaluation of GGCM-based differences in capturing historical national yield variation. The group of models include several with common origins, as described by Rosenzweig et al. (2014; Supplementary Information); however, large variations in included model processes, configuration settings and calibration datasets mean that each of the models in the ensemble are substantially distinct from one another (see Müller et al., 2019, and Supplementary Information S2). Folberth et al. (2019) further evaluated differences in the 5 different modeling group simulations stemming from the EPIC model, finding that yield estimates were distinguished by differences in model versions, parameterization, management assumptions (beyond those harmonized within GGCMI), soil attributes, and cultivar distributions.

\subsection{Simulation subsets and ensembles for analysis}

Table 2 shows the complete set of GGCM Phase 1 simulations, which were run for both rainfed and irrigated conditions. Gaps in the table reflect that resource and structural constraints limited the ability of many modeling teams to run every requested combination of CFD, configuration and crop species. In order to achieve complete multimodel coverage for at least two WFDs, each GGCM was specifically requested to run the AgMERRA and WFDEIgpcc CFDs and then as many additional CFDs as resources allowed. There are relatively fewer simulation outputs submitted for the GSWP3 and PGFv2 CFDs as these were added to the GGCMI protocol later in the project timeline. As our interest is in determining the response of GGCMs to the CFDs' growing season climate, we prioritize the simulations with consistent planting and harvest dates ([H and $\mathrm{N}]>\mathrm{D}$ ) and selected configurations that included nitrogen limitations where available $(\mathrm{H}>\mathrm{N})$, resulting in a final prioritization of $\mathrm{H}>\mathrm{N}>\mathrm{D}$ (see Supplementary S2 for further model and configuration information). Analysis here focuses on the relative seasonal anomalies for each GGCM simulation, which are a better reflection of climatic response than the raw anomalies influenced by mean bias and further questions of model configuration such as soil nitrogen and cultivar characteristics (Müller et al., 2017).

To isolate the implications of the CFD selection in the full ensemble, we identify two types of GGCM-CFD groupings that sample across the crop model dimension:

'+' subset [per CFD]: A consistent subset of GGCMs across CFDs, representing the 7 GGCMs ( 5 for rice) that ran most CFDs (underlined in Table 2): EPIC-BOKU, EPIC-TAMU, LPJ-GUESS, LPJmL, pAPSIM, pDSSAT and PEGASUS, using the bolded and underlined configuration in Table 2. The 'AgMERRA+' subset, for example, is the ensemble average of these 7 GGCMs simulating the AgMERRA CFD using the specified configuration.

'All' subset [per CFD]: All GGCMs that ran a given CFD, using the bolded configuration. The 'AgMERRA_all' subset, for example, includes all GGCMs that ran the AgMERRA CFD using the specified configuration.

We also form ensembles across both the climate and crop model dimensions of GGCMI in order to look at overall GGCMI performance:

'Ensemble+' subset: All GGCMs that were included in the + ensembles across all CFDs (bolded and underlined in Table 2). This represents the aggregate performance of the core set of GGCMs that ran most CFDs.

'Ensemble-all' subset: All GGCM/CFD combinations marked as bold in Table 2 (e.g., 91 model simulations in total for maize). To our knowledge this is the largest GGCM/CFD ensemble to have been constructed, and we examine it here to quantify the potential added 
Table 2

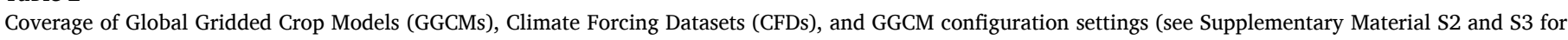

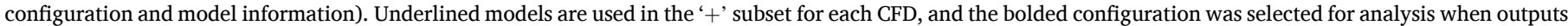
from multiple configurations were submitted for a given GGCM.

\begin{tabular}{|c|c|c|c|c|c|c|c|c|c|c|c|c|}
\hline & & \multicolumn{11}{|c|}{ Climatic Forcing Datasets } \\
\hline & & AgCFSR & AgMERRA & CFSR & ERAI & GRASP & GSWP3 & PGFv2 & Princeton & WATCH $\$$ & WFDEICru & WFDEIgpcc \\
\hline \multirow{14}{*}{ 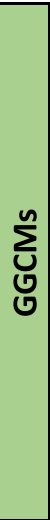 } & CGMS-WOFOST & & D & & & & & & & & & D \\
\hline & CLM-Crop & & $H, N, D$ & & & & & & & & & $\mathrm{H}, \mathrm{N}, \mathrm{D}$ \\
\hline & EPIC-BOKU & H, N, D & $\underline{H}, N, D$ & $\underline{\mathrm{H}}, \mathrm{N}, \mathrm{D}$ & $\underline{H}, \mathrm{~N}, \mathrm{D}$ & $\underline{H}, \mathrm{~N}, \mathrm{D}$ & $\mathrm{H}, \mathrm{N}, \mathrm{D}$ & $\mathrm{H}, \mathrm{N}, \mathrm{D}$ & $\underline{\mathrm{H}}, \mathrm{N}, \mathrm{D}$ & $H, N, D$ & $\underline{\mathrm{H}}, \mathrm{N}, \mathrm{D}$ & $\underline{H}, \mathrm{~N}, \mathrm{D}$ \\
\hline & EPIC-IIASA ^ & $\mathrm{H}, \mathrm{N}$ & $H, N, D$ & & & H & & & & $\mathrm{H}, \mathrm{D}$ & & $\mathrm{H}, \mathrm{N}, \mathrm{D}$ \\
\hline & EPIC-TAMU * & $\underline{H}, \mathrm{~N}$ & $\underline{H}, \mathrm{~N}$ & $\underline{\mathrm{H}}, \mathrm{N}$ & $\underline{\mathrm{H}}, \mathrm{N}$ & $\underline{H}, \mathrm{~N}$ & & & $\underline{H}, \mathrm{~N}$ & $\mathrm{H}, \mathrm{N}$ & $\underline{H}, \mathrm{~N}$ & $\underline{H}, \mathrm{~N}$ \\
\hline & GEPIC & $\mathrm{H}$ & $H, N, D$ & & & $\mathrm{H}$ & & D & & $\mathrm{H}$ & & $\mathrm{H}, \mathrm{N}, \mathrm{D}$ \\
\hline & LPJ-GUESS & $\underline{\mathbf{N}}$ & $\underline{\mathbf{N}}, \mathrm{D}$ & $\underline{\mathbf{N}}$ & $\underline{\mathbf{N}}$ & $\underline{\mathbf{N}}$ & D & $\mathrm{N}, \mathrm{D}$ & $\underline{\mathbf{N}}$ & $\mathrm{N}$ & $\underline{\mathbf{N}}$ & $\underline{\mathbf{N}}, \mathrm{D}$ \\
\hline & $\underline{\mathrm{LPJmL}}$ & $\underline{\mathbf{N}}, \mathrm{D}$ & $\underline{\mathbf{N}}, \mathrm{D}$ & $\underline{\mathbf{N}}, \mathrm{D}$ & $\underline{\mathbf{N}}, \mathrm{D}$ & $\underline{\mathbf{N}}, \mathrm{D}$ & D & $\mathbf{N}, \mathrm{D}$ & $\underline{\mathbf{N}}, \mathrm{D}$ & $N, D$ & $\underline{\mathbf{N}}, \mathrm{D}$ & $\underline{\mathbf{N}}, \mathrm{D}$ \\
\hline & pAPSIM & $\mathrm{H}, \mathrm{N}, \mathrm{D}$ & $\underline{H}, \mathrm{~N}, \mathrm{D}$ & $\mathrm{H}, \mathrm{N}, \mathrm{D}$ & $\mathrm{H}, \mathrm{N}, \mathrm{D}$ & $\mathrm{H}, \mathrm{N}, \mathrm{D}$ & & & H, N,D & $\mathrm{H}, \mathrm{N}, \mathrm{D}$ & $\mathrm{H}, \mathrm{N}, \mathrm{D}$ & H, N, D \\
\hline & pDSSAT & $\underline{\mathrm{H}}, \mathrm{N}, \mathrm{D}$ & $\underline{\mathrm{H}}, \mathrm{N}, \mathrm{D}$ & $\underline{\mathrm{H}}, \mathrm{N}, \mathrm{D}$ & $\underline{\mathrm{H}}, \mathrm{N}, \mathrm{D}$ & $\underline{\mathrm{H}}, \mathrm{N}, \mathrm{D}$ & & & $\underline{\mathrm{H}}, \mathrm{N}, \mathrm{D}$ & $\mathrm{H}, \mathrm{N}, \mathrm{D}$ & $\underline{\mathrm{H}}, \mathrm{N}, \mathrm{D}$ & $\underline{\mathrm{H}}, \mathrm{N}, \mathrm{D}$ \\
\hline & PEGASUS & $\underline{H}$ & $\underline{\mathrm{H}}, \mathrm{N}, \mathrm{D}$ & $\underline{H}$ & $\underline{H}$ & & & & $\underline{\mathrm{H}}$ & $\mathrm{H}$ & $\underline{\mathrm{H}}$ & $\underline{\mathrm{H}}, \mathrm{N}, \mathrm{D}$ \\
\hline & ORCHIDEE-CROP & & $H, N, D$ & & & & $\mathrm{H}, \mathrm{D}+$ & & $\mathrm{H}, \mathrm{N}, \mathrm{D}++$ & & & $H, N, D+++$ \\
\hline & PEPIC & $\mathrm{H}, \mathrm{N}, \mathrm{D}$ & $\mathrm{H}, \mathrm{N}, \mathrm{D}$ & & & $\mathrm{H}, \mathrm{N}, \mathrm{D}$ & $\mathrm{H}, \mathrm{N}, \mathrm{D}$ & $\mathrm{H}, \mathrm{N}, \mathrm{D}$ & & & $\mathrm{H}, \mathrm{N}, \mathrm{D}$ & $\mathrm{H}, \mathrm{N}, \mathrm{D}$ \\
\hline & PRYSBI2 + & D & D & & & D & & & D & D & D & D \\
\hline
\end{tabular}

^ EPIC-IIASA did not run Rice with AgCFSR or WFDElgpcc

* EPIC-TAMU only ran Maize and Wheat

$\sim$ PAPSIM and PEGASUS did not run Rice

+ PRYSBI 2 only ran irrigated lands

$\$$ WATCH only goes to 2001; not included in ensemble

\begin{tabular}{|l|l|}
\hline Simulations Available & GGCM Configurations \\
\hline 1 Configuration & $\mathrm{H}=$ Harmonized \\
2 Configurations & $\mathrm{N}=$ No N Limitation \\
3 Configurations & $\mathrm{D}=$ Default \\
\hline
\end{tabular}

+ No Rice with $\mathrm{H}$

t† No Wheat with $\mathrm{H}$, no Rice or Wheat with $\mathrm{N}$,

only Rice with D

††+ Only Rice and Wheat with $\mathrm{N}$ benefit given that the resources required for such large community efforts typically preclude their use for individual applications.

Each of these subsets is designed to build on AgMIP findings that the statistics of an ensemble of models performs better than any single model when evaluated across a broad spectrum of environments and systems (Bassu et al., 2014; Fleisher et al., 2017; Jägermeyr et al., 2020; Martre et al., 2015; Müller et al., 2017; Nelson et al., 2014; Wallach et al., 2015; Zhao et al., 2017). Consequently, no model is given more weight within any particular ensemble when calculating ensemble statistics (Wallach et al., 2016). Müller et al. (2017) provide analysis of individual GGCM performance, which is not our focus here,

Analysis of the ' + ' subsets for each CFD therefore provides unprecedented insight into these CFDs' effects on agricultural simulations with a consistent crop model ensemble rather than being dependent on a single crop model. Note that the ' + ' ensemble contains 7 models for maize, wheat, and soybean, but only 5 models for rice given that pAPSIM and PEGASUS did not provide data for rice. The ' + ' ensemble includes two EPIC GGCMs but these employ different core EPIC model versions and a number of differences in configuration for soils and management (Folberth et al., 2019). The 'All' subsets indicate whether the inclusion of additional GGCMs would have altered the ensemble's response to the CFD response. These contrast with the 'Ensemble-all' subset that provides the overall GGCMI Phase 1 ensemble performance, which benefits from both an ensemble of CFDs and GGCMs although the relative weight of each depends on the outputs provided (Table 2). An example of GGCM/CFD ensemble construction is provided for Romanian maize production anomalies in Figure S.2.

\subsection{Production datasets and processing}

GGCMs simulate crop yields (t/ha) that must be converted to production (total $\mathrm{kg}$ ) using harvested area masks in order to compare against observational production datasets. We calculate national-level production from the $0.5^{\circ} \times 0.5^{\circ}$ grid using harvested crop areas from the Spatial Production Allocation Model v2.0 (SPAM), which approximates the year 2005 and does not change from year to year (You et al., 2014). We aggregate rainfed and irrigated production values separately using the corresponding GGCMI simulations and SPAM areas, then use the sum of rainfed and irrigated production for national or global totals (following Ruane et al., 2018bb; Porwollik et al., 2017).

Reference national production data are drawn from the United Nations Food and Agricultural Organization (http://www.fao. org/faostat/en/\#data). These data are reported by governments and include heterogeneous cultivars, planting dates, fertilizer applications, irrigation methods, farm management, and soils that cannot be fully represented by GGCMI's relatively coarse resolution configurations. FAOstat data also reflect agricultural trends and anomalies beyond those driven solely by field-level climate such as the effects of technological improvements, mechanization, agricultural sector development, labor supply, geopolitical conflict, crop pests and diseases, and large-scale disasters (e.g., earthquakes, floods, hurricanes). Overall, Ray et al., (2015) estimated that the climate signal explains only about a third of observed global interannual yield variability. For these reasons we detrend FAOstat data and crop model outputs. GGCMI has explored multiple methods for detrending including first-difference, linear and polynomial fits, and there is a clear tradeoff between consistency in methods and unique characteristics in production time series that defy general approaches. While further efforts to isolate the climate signal in national production datasets using a blend of locally-selected detrending techniques would be beneficial to GGCMI and the broader agricultural community, here we calculate anomalies from a 5-year moving average and compare against similarly detrended GGCMI outputs (as described in Müiller et al., 2017, and further evaluate in Supplemental Materials S8). We assign each simulated growing season according to the average harvest date for the purpose of time series correlations, which can cause an occasional mismatch with FAO data that assigns harvests to the growing season in which the majority of the growing period occurs, leading to occasional differences for locations and seasons with early or late harvests that are on the other side of New Year's day than the average harvest date. Additional information on the use of production datasets is provided in Supplementary Materials S4.

To understand the role of climate variability on a sub-national scale we also employ the detrended United States Department of Agriculture's National Agricultural Statistics Service (USDA NASS) county-level 
production (https://quickstats.nass.usda.gov/). NASS production data are collected using reported and surveyed yields. We combine the average of NASS 1981-2010 county-level cropped areas with simulated yields to calculate simulated county-level production for comparison to NASS production anomalies.

We analyze uncertainty by determining the relative variation across ensemble members for each year compared to the variation of the ensemble median across years. Anomalies of precipitation and yield are first calculated as percentages to remove the effects of mean biases. We then calculate a standardized anomaly, which is the ratio of (i) the standard deviation of yearly ensemble member anomalies (compared to the ensemble mean) to (ii) the standard deviation of the ensemble mean time series itself. Standardized anomalies $>1$ therefore indicate that a given annual anomaly is more likely due to ensemble member differences, while standardized anomalies $<1$ indicate that anomalies are likely representative of true interannual variation. Supplementary Material S.7 provides further detail on this method as well as two contrasting examples (Figure S.5).

\section{Differences between climatic forcing datasets}

CFD regional differences can be measured in myriad ways, including in their mean quantities, statistical distributions, sequencing of events, variable relationships, modes of variability, long-term trends, and spatial coherence. While a comprehensive atlas of CFD differences for each growing season is beyond the scope of this paper, Fig. 1 provides the median of the CFD-all ensemble for the rainfed maize growing season as well as biases for AgMERRA and WFDEIgpcc, which are the CFDs most commonly used within GGCMI Phase 1. Corresponding bias maps for the other CFDs are provided in Supplementary Figures S.2-S.4. It is important to emphasize that the CFD-all median is not necessarily the true value given common biases in observational datasets and methods across CFDs. Computing the median is likely to reduce some of the more outlying values, however; and therefore serves as a 'best-guess' basis to help us identify CFD differences that are likely relevant to agricultural production. The Princeton CFD was not included in these CFD-all climate maps because it ends in 2008, and because it displayed a checkerboardlike spatial bias pattern for precipitation threshold statistics. This suggests errors in re-gridding and/or interpolation of daily sequences in the GGCMI processing of that dataset, although this pattern was not apparent in the mean precipitation rate or other variables. The following metrics are evaluated for the rainfed maize growing season and cultivation regions as an example given that maize is an important staple crop with widespread cultivation.

\subsection{Mean growing season metrics}

Median CFD-all mean temperature in the rainfed maize growing season (Fig. 1a) generally follows mean climatological patterns with warmer conditions in the Tropics and cooler conditions at higher latitudes, as maize generally corresponds to the warm season unless part of a multi-cropped region. CFD differences for mean temperature are generally low $\left(<1^{\circ} \mathrm{C}\right)$. AgMERRA (Fig. 1b) is slightly cooler than CFD-all in most of the United States, South America, Africa, Europe, and Indonesia, and is slightly warmer in South and East Asia as well as the Middle East, Mexico, and South America west of the Andes. WFDEIgpcc (Fig. 1c) has generally the opposite differential pattern for the United States and Asia, and is also cooler than CFD-all in Europe, East Africa, and southern South America.

Median CFD-all mean precipitation rate (Fig. 1g) reflects that rainfed maize generally grows during the local wet season. AgMERRA is generally very close to the median CFD, with a slight dry bias $(\approx 5 \%)$ in Southern Russia and scattered small regions around the world. WFDEIgpcc has a widespread wet bias with prominent differences $>10 \%$ in the US Midwest, southern South America, central Africa, Europe, and eastern India. Dry bias pockets $>10 \%$ are less common, but include southwest India and Myanmar.

Solar radiation in the CFD-all (Fig. 1p) reflects a combination of latitude, aridity, and seasonality of the growing period, with cloudier conditions in the moist Tropics and reduced solar radiation in the cool season maize in SE China and northern Mexico. AgMERRA has solar radiation very close to the ensemble median. This is likely because many CFDs used the same NASA/GEWEX SRB information (Stackhouse, Jr et al., 2011) and the others did not substantially differ on aggregate. WFDEIgpcc is generally cloudier in the tropics and sunnier at midlatitudes $\left(\approx+/-1.5 \mathrm{MJ} / \mathrm{m}^{2} /\right.$ day $)$.

\subsection{Distributional statistics within the growing season}

Days where maximum temperature exceeds $35^{\circ} \mathrm{C}$ (Fig. 1d) are associated with negative impacts on maize pollination and production (Hatfield and Prueger, 2015), and patterns of this extreme temperature are a reasonable proxy for similar heat stress thresholds of wheat, rice, and soybean (Deryng et al., 2014; Schauberger et al., 2017). The median CFD-all sees more of these extreme heat days along the fringes of the major growing areas, including in the Sahel, Central Asia, NE Brazil, and the SW Great Plains and NE Mexico. AgMERRA is similar to CFD-all in major breadbaskets of the Central United States, Europe, and East Asia but tends to underestimate these days (by $\approx 10$ ) in many tropical areas while overestimating them in semi-arid zones of Southern Africa, Southern South America, Central and West Asia, and the western Great Plains. WFDEIgpcc has an overall tendency towards more extreme heat days than CFD-all (by $\approx 10-15$ in many regions), particularly in North America and along the fringes of the Amazon although it is similar to CFD-all in Europe and East Asia. WFDEIgpcc has more extreme heat even in several regions that showed an overall cool bias in mean temperature, suggesting a larger diurnal temperature range or broader distribution of daily extremes.

The number of wet days ( $\mathrm{P}>0 \mathrm{~mm}$ ) within a growing season is an important proxy for the likelihood of dry spells and the overall proportion of precipitation that reaches the root zone (as opposed to running off). CFD-all median number of precipitation days per growing season (Fig. 1j) has a pattern generally similar to the mean growing season precipitation rate. AgMERRA has fewer wet days in most maizegrowing regions (especially in Africa, Mexico and South Asia), while WFDEIgpcc has more wet days (particularly in Africa, Southern South America, Eastern Europe, and the foothills of the Hindu-KushHimalayas). These differences are likely due to the additional biasadjustment of the number of precipitation days within AgMERRA, AgCFSR, and GRASP which corrects a common drizzle-bias in reanalyses and leads to lower numbers than the CFD-all median.

Heavy precipitation days can be problematic for crops given that they are often associated with nitrogen leaching, and a larger proportion of total precipitation that falls as heavy precipitation events can reduce the overall soil infiltration and heighten the risk of low soil column spells. The median CFD-all number of days where $\mathrm{P}>20 \mathrm{~mm}$ (Fig. 1n) has similar spatial patterns to the mean precipitation field, with the most frequent heavy events in the Amazon and monsoon regions of Asia. Different crop systems and soil profiles may have distinct thresholds for pluvial flooding and high runoff proportions, but we employ P $>20 \mathrm{~mm}$ as representative of the higher tail of the distribution and note that these days likely consist of heavier daily totals in smaller regions within the larger grid cell (see Supplementary Material S9). AgMERRA has more heavy wet days in the Tropics $(\approx 3$ more) and Western Africa in particular, likely as a secondary consequence of the reduction in drizzle days resulting in fewer (but more intense) precipitation events to match monthly totals. WFDEIgpcc has fewer very wet days than CFD-all with nearly the opposite geospatial pattern of bias as AgMERRA but more substantial reduction over the rainforests of Central Africa. 
a) CFD-all mean temperature

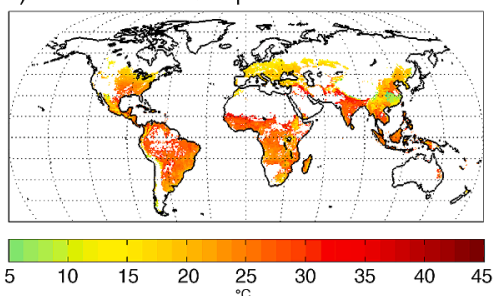

d) CFD-all \# days $\mathrm{T}>35^{\circ} \mathrm{C}$
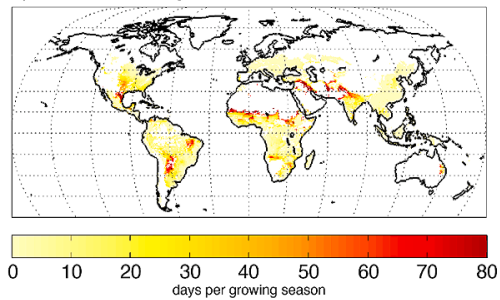

g) CFD-all mean precipitation

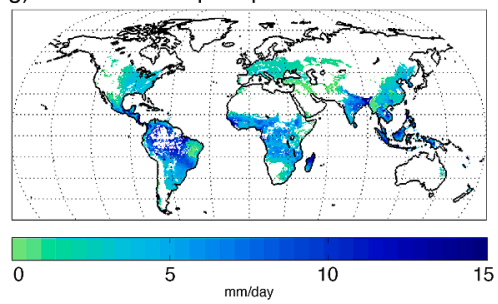

j) CFD-all \# days $P>0 \mathrm{~mm}$

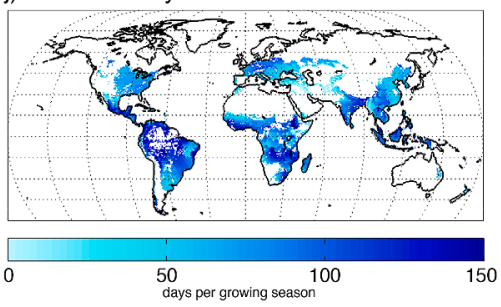

m) CFD-all \# days $P>20 \mathrm{~mm}$

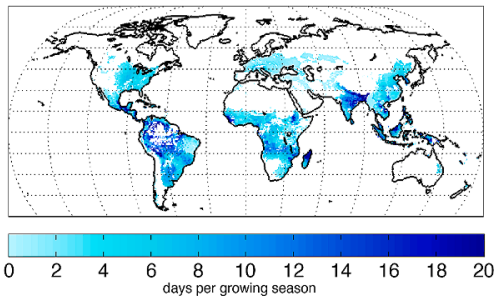

p) CFD-all mean solar radiation

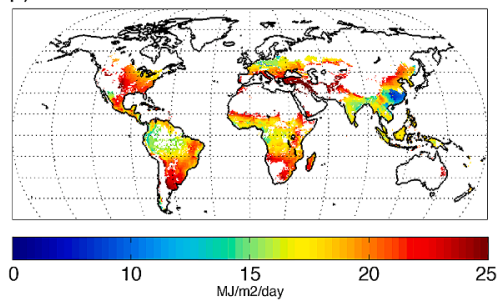

b) AgMERRA mean temperature deviation

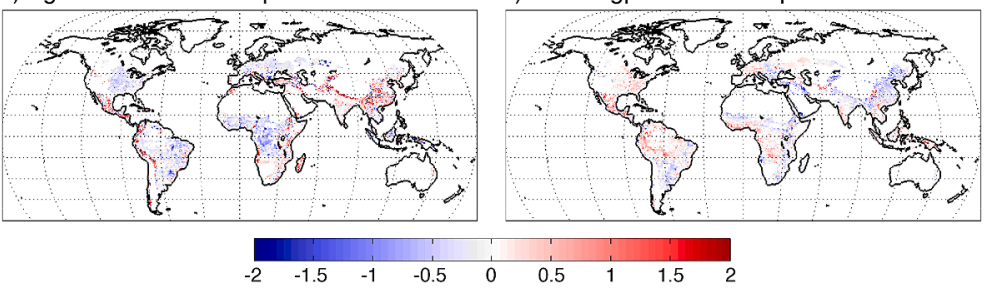

e) AgMERRA \# days $\mathrm{T}>35^{\circ} \mathrm{C}$ deviation f) WFDElgpcc \# days $\mathrm{T}>35^{\circ} \mathrm{C}$ deviation

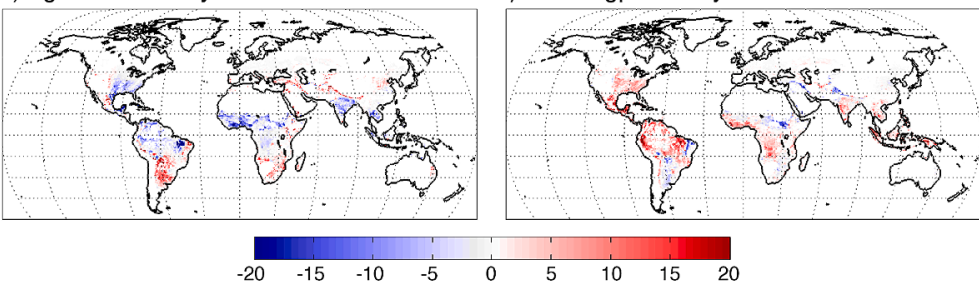

h) AgMERRA mean precipitation deviation $\quad$ i) WFDEIgpcc mean precipitation deviation

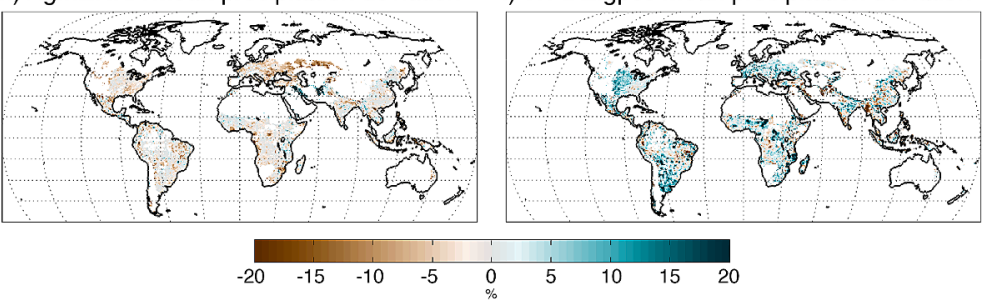

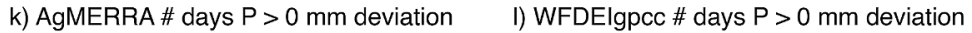
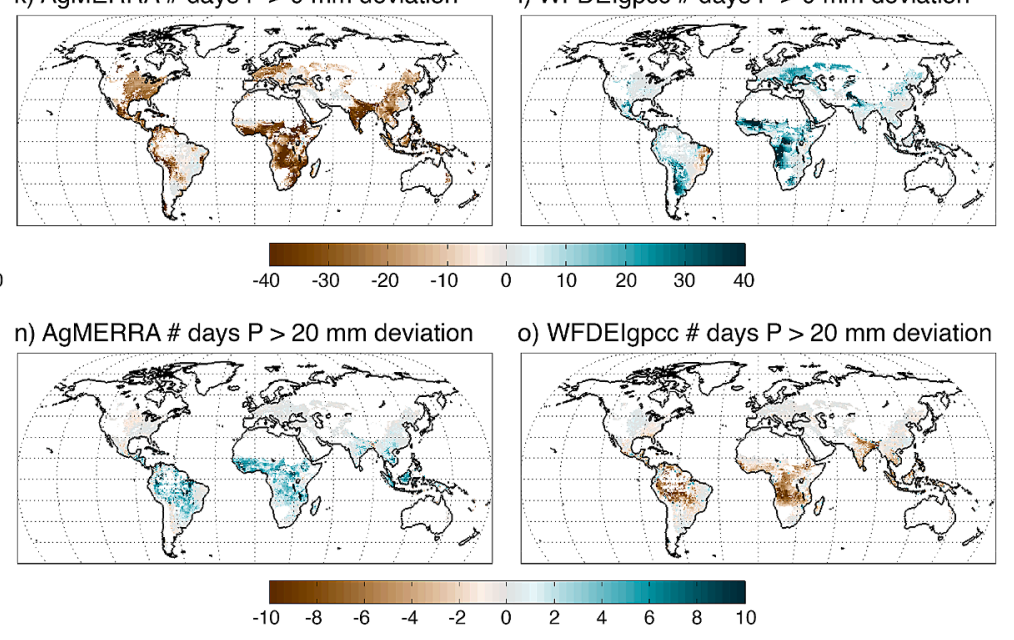

q) AgMERRA mean solar radiation deviation r) WFDElgpcc mean solar radiation deviation

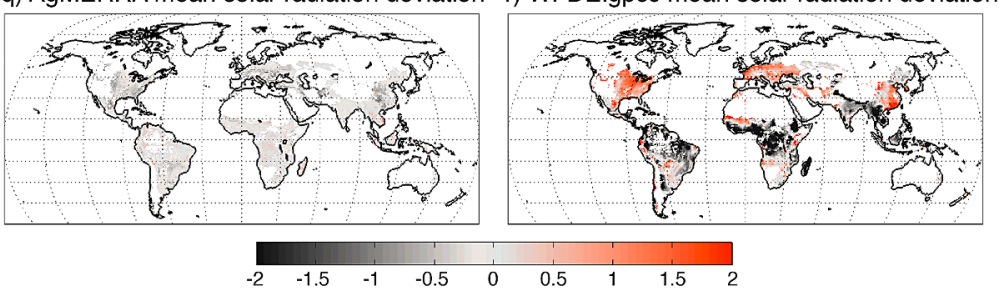

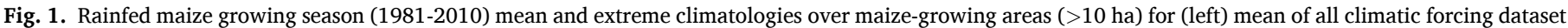

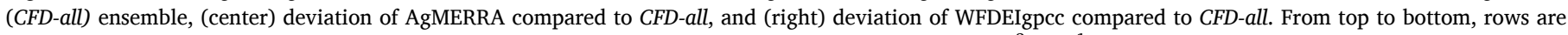

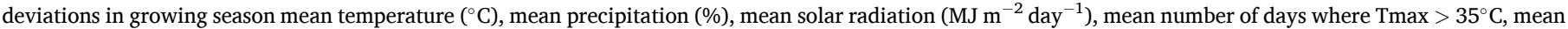

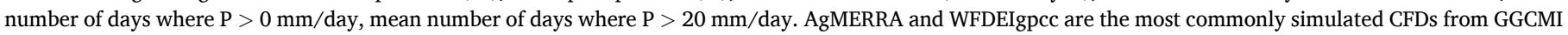
Phase 1; corresponding deviation maps for other CFDs are shown in Figures S.3-S.5. 


\section{GGCM response to interannual climate}

In order to understand the geographical distribution of climatic uncertainty, Fig. 2a,c shows the standardized anomalies of rainfed maize growing season temperatures and precipitation from CFD-all, revealing the places where the CFD ensemble is less clear than a typical annual anomaly. High values over the Western Amazon, Central and Western Africa, and Borneo reflect the difficulty of obtaining high quality observational data in these regions. Standardized temperature anomalies above one, indicating CFD variance is greater than interannual variance, are also seen across much of Africa, the Hindu-KushHimalayas and Mexico, while lower values reflect larger interannual variance and consistent observational data across North America, Europe, Southeast Africa, India, East Asia, and Eastern South America.
Most maize-growing areas that show high standardized temperature anomalies also show high standardized precipitation anomalies, with additional regions of larger CFD uncertainty for precipitation over EastCentral Africa, the Middle East, Central Asia, and Southeast Asia.

Standardized anomalies of Ensemble-all rainfed maize yield simulations (Fig. 2e) reflect many of the patterns seen in the standardized anomalies of growing season temperature and precipitation, underscoring the role of climate uncertainty in the overall simulation uncertainty. Standardized anomalies for simulated yield (peaking above 5 in some locations) are much larger than for the climate variables (which peaked closer to 2), suggesting strong interactions between uncertain GGCM configurations and climate variability within the simulated yields. High uncertainties are particularly prominent in developing countries, where crop simulation models are typically more difficult to

\section{a) Standardized rainfed maize growing season} temperature anomaly

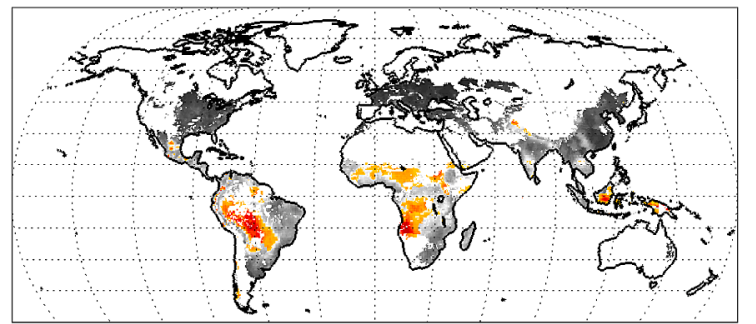

\section{b) Standardized rainfed rice growing season} temperature anomaly

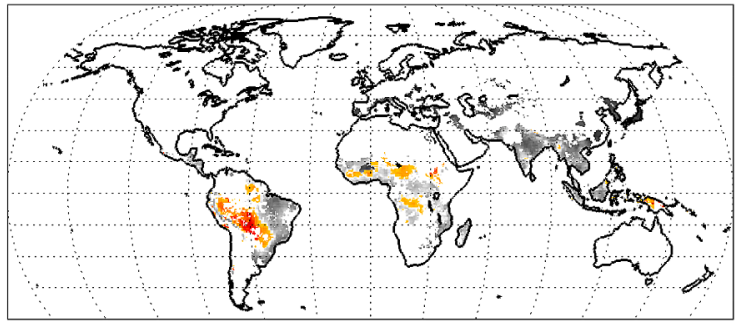

$\begin{array}{lllllllllll}0 & 0.2 & 0.4 & 0.6 & 0.8 & 1 & 1.2 & 1.4 & 1.6 & 1.8 & 2\end{array}$

c) Standardized rainfed maize growing season precipitation anomaly

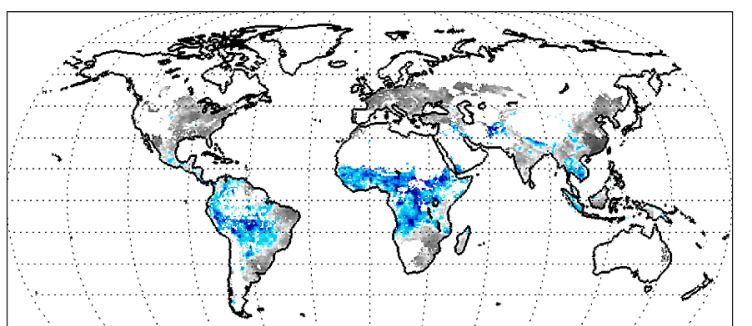

d) Standardized rainfed rice growing season precipitation anomaly

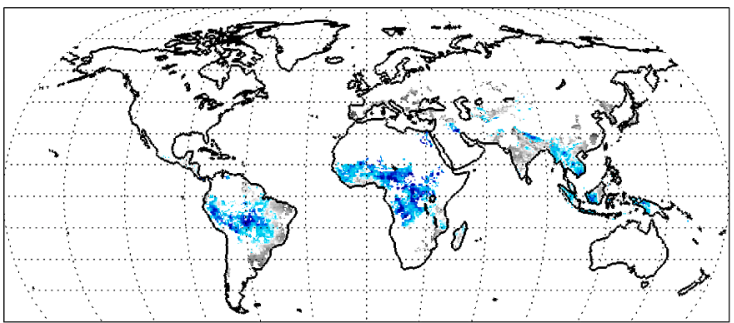

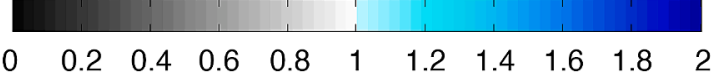

e) Standardized rainfed maize yield anomaly

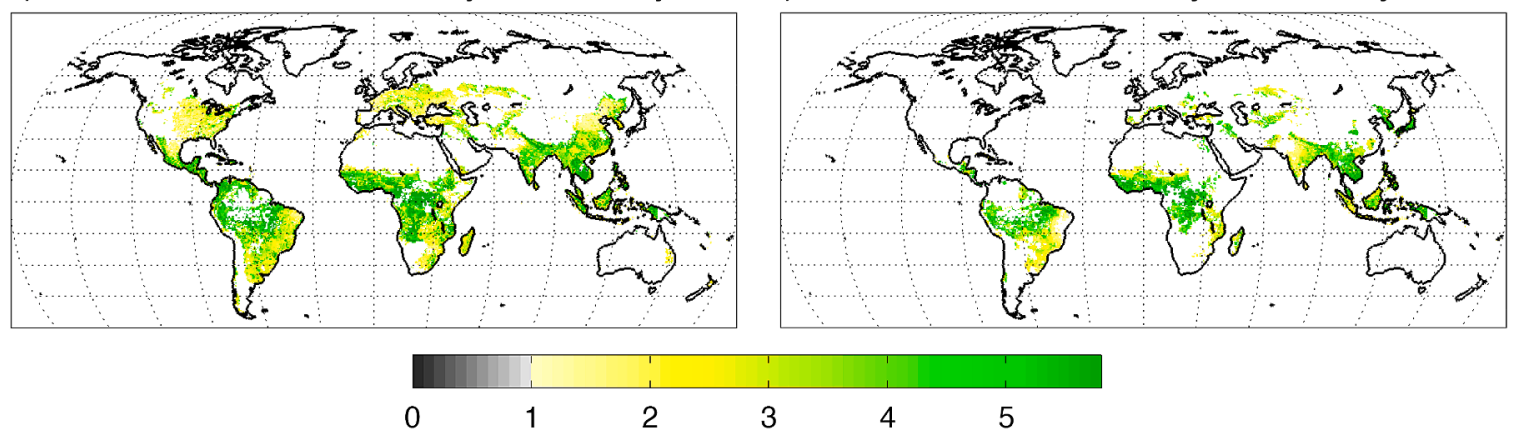

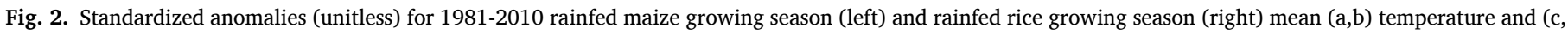

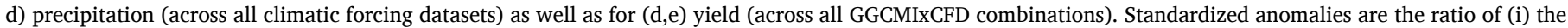

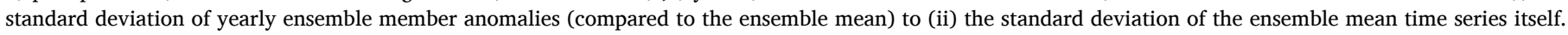

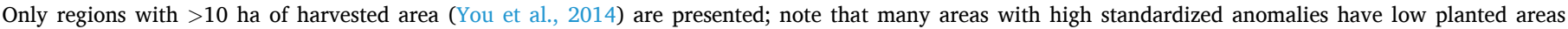
(Figure S1). 
configure given the relative lack of observational climate, soils, and agronomic data, their greater proportion of small-holder farms, and heterogeneous cultivars and management that may not be consistently represented across GGCMs (Fritz et al., 2015). Regions with lower fertilizer usage have additional interactions between nitrogen stress and heat or water stress driven by climate, which would only be captured in GGCMs including nitrogen dynamics. Very few places have standardized yield anomalies below 1 .

Standardized anomalies for the wheat and soybean (Supplementary Figure S.2) have similar patterns, with lower standardized anomalies for temperature than precipitation and the highest standardized anomalies coming from the simulated yield. Major production regions for maize, wheat, and soybean, which tend to be in the middle latitudes, typically have standardized anomalies $<1$ for climate variables, however the major production regions for rice (Fig. $2 \mathbf{b}, \mathbf{d}, \mathbf{f}$ ) in Southeast Asia have standardized precipitation anomalies $>1$, corresponding with substantial yield uncertainty likely dependent on CFD selection.
Fig. 3 shows the correlation between median Ensemble-all yields with the median CFD-all growing season mean temperature, precipitation, and solar radiation to identify regional and crop-specific agroclimatic sensitivities. These fundamental climate responses motivate agricultural management decisions to reduce risk and point to areas where uncertainty in CFD variables is likely to strongly affect simulated yields. Higher correlations do not necessarily mean more accurate simulations, only that the GGCM simulations for a given crop have a strong and consistent response to regional variation of a particular climate variable.

Rainfed maize, wheat, rice, and soybean simulations each follow a common interannual pattern dominated by precipitation, with a positive correlation associating wet years with higher yields and the worstyielding years generally associated with drought. This relationship is strongest in areas with marginal rainfall totals and low irrigation, including NE Brazilian maize, wheat in the western Great Plains of North America, rice in the Sahel, and soybean in SE Europe. Temperature correlations are broadly negative, indicating that yields are higher in a) Rainfed maize yield vs. temperature

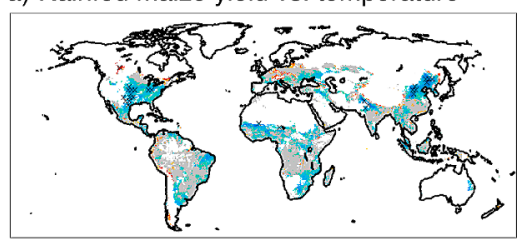

d) Rainfed wheat vs. temperature

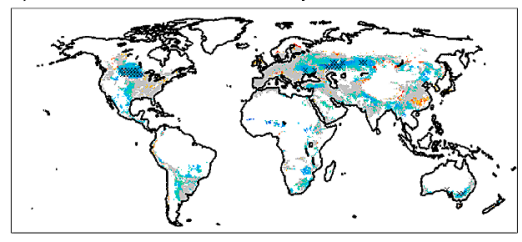

g) Rainfed rice vs. temperature

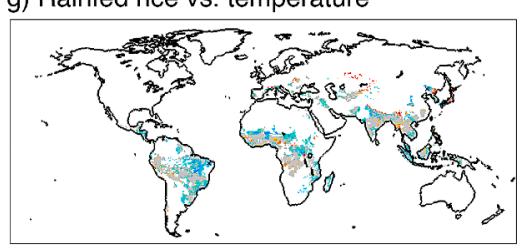

j) Rainfed soybean vs. temperature

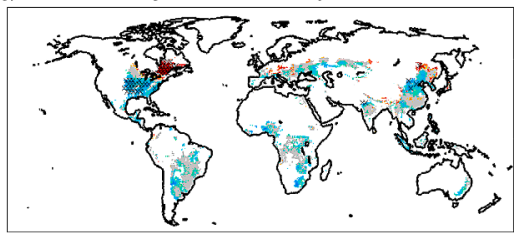

m) Irrigated maize vs. temperature

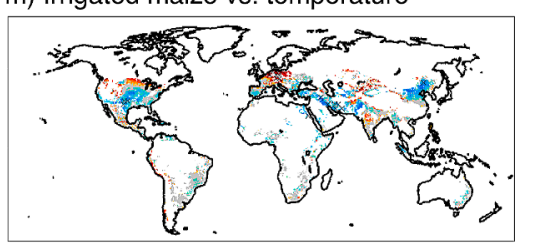

b) Rainfed maize yield vs. precipitation

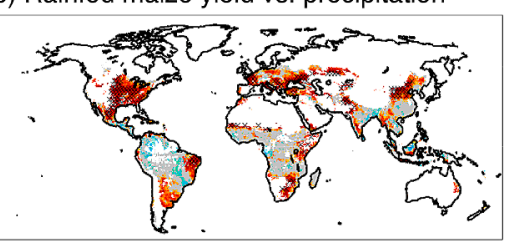

e) Rainfed wheat vs. precipitation

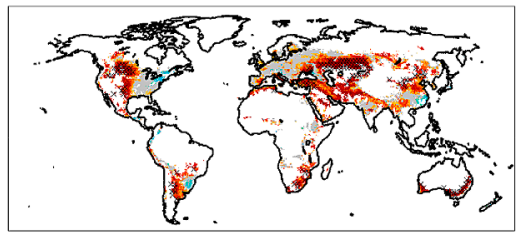

h) Rainfed rice vs. precipitation

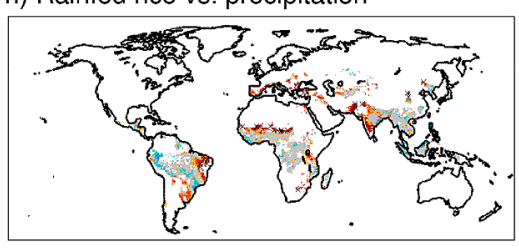

k) Rainfed soybean vs. precipitation

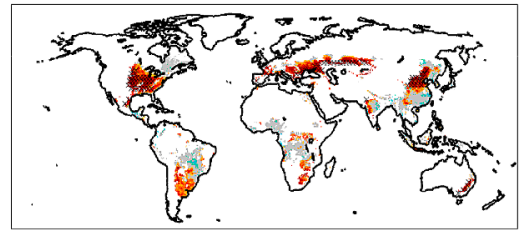

n) Irrigated maize vs. precipitation

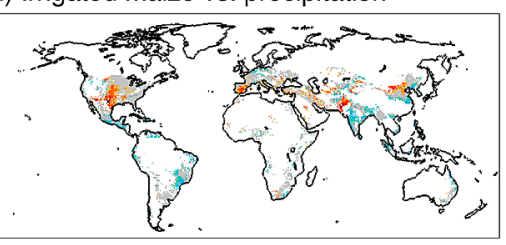

c) Rainfed maize yield vs. solar radiation

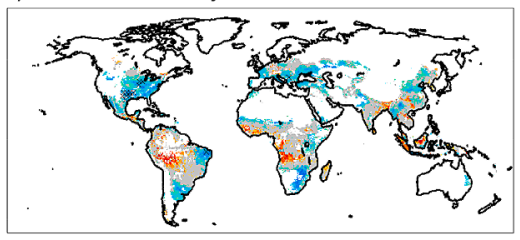

f) Rainfed wheat vs. solar radiation

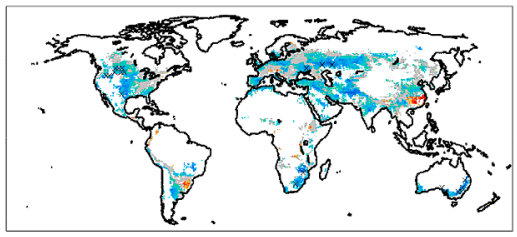

i) Rainfed rice vs. solar radiation

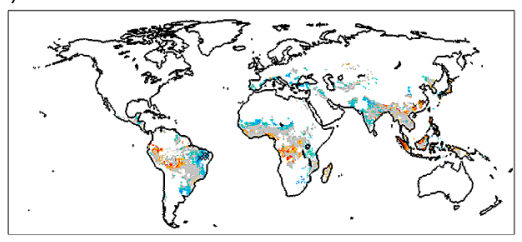

l) Rainfed soybean vs. solar radiation

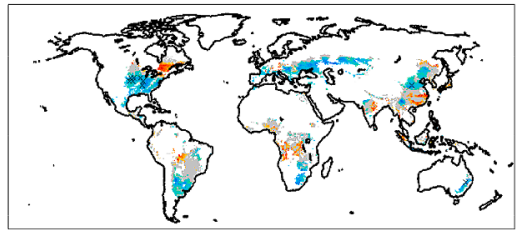

o) Irrigated maize vs. solar radiation

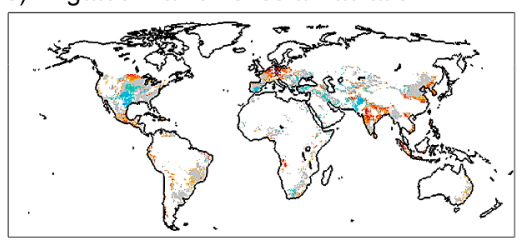

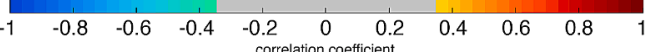

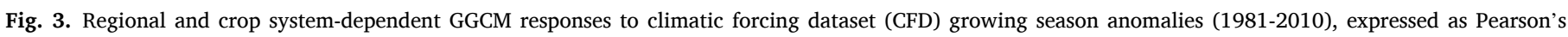

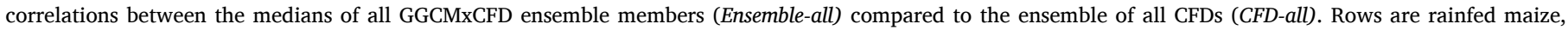

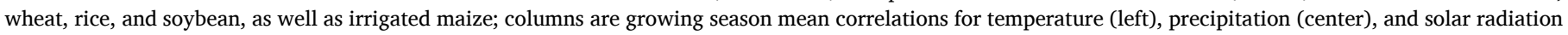

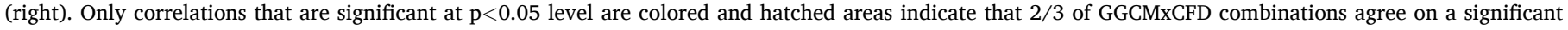
correlation in the same direction. Only regions with $>10$ ha of harvested area (You et al., 2014) are presented. 
cool years and depressed in hotter conditions. Regional pockets show a positive correlation with temperature, indicating that warmer conditions can be beneficial along the cooler poleward and high-elevation fringes. Yield is often negatively correlated with seasonal solar radiation anomalies, which is likely a reflection of cross-correlations in the climate system whereby higher precipitation is associated with cloudier weather and droughts with clearer skies. It is also likely that high temperatures are cross-correlated with drier conditions and higher potential evapotranspiration.

Exceptions to this general pattern are also illustrative, as apparent in diverse median responses and a lack of consistency across GGCM/CFD combinations (represented by the hatching in Fig. 3). Most crops are less sensitive to seasonal climate metrics in the moist tropics, where water is less often a limiting factor and interannual variations are generally small compared to the average growing season total. These areas are likely more responsive to shifts in sub-seasonal characteristics such as heat waves and the onset, exit, break periods, and intense precipitation events within rainy seasons. Rice, which is often grown in those moist tropical regions, is the least dependent on seasonal climate anomalies, a result consistent with the finding of reduced sensitivity to climate variability by Ray et al. (2015).

A comparison between rainfed and irrigated maize (top and bottom rows of Fig. 3, respectively) highlights the ways in which water management affects climate response, most notably by reducing the dependence on precipitation anomalies. Simulations of irrigated maize are not completely absent of precipitation response, however; showing signs that modeled irrigation management does not eliminate water stress in places like Texas, Spain, the Indus Basin, and Northern China. Negative responses to wet seasons may reflect nutrient leaching under increased runoff in Central America, Northern Europe, and India. Irrigated maize in Northern Europe and the northern Great Plains has an enhanced positive response to temperature compared to the rainfed maize, possibly related to a reduction in water stress that can accompany a warmer season's higher evapotranspiration demand. Irrigated areas also have relatively higher correlations with solar radiation as water supply diminishes the effects of the cross-relationship between sunshine and drought conditions. a) Rainfed maize LPJmL-AgMERRA vs. LPJmL-all

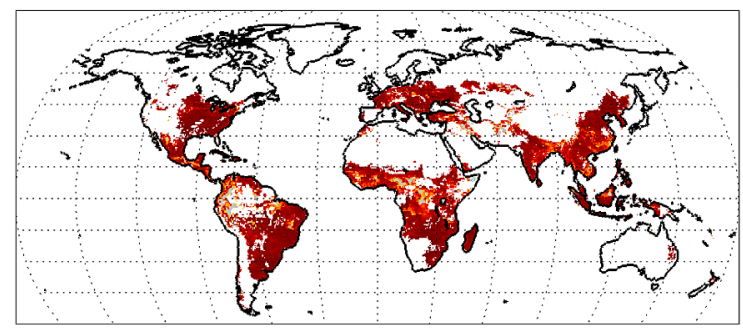

c) Rainfed maize EPIC_TAMU-AgMERRA vs. EPIC_TAMU-all

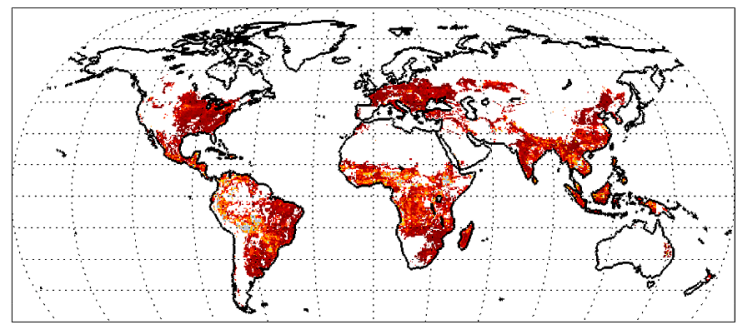

\section{d) Rainfed maize EPIC_TAMU-WFDElgpcc vs.} EPIC_TAMU-all

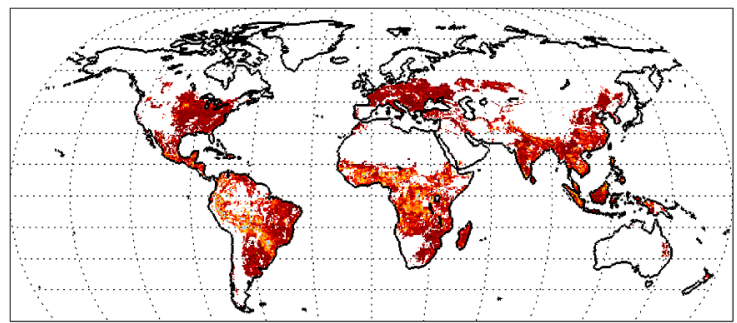

f) Rainfed rice LPJmL-WFDElgpcc vs. LPJmL-all

e) Rainfed rice LPJmL-WFDEIcru vs. LPJmL-all

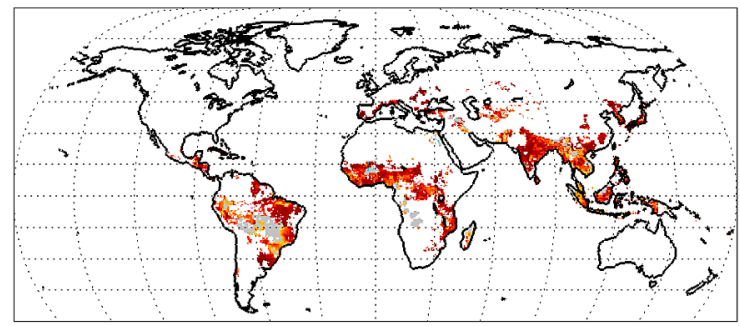

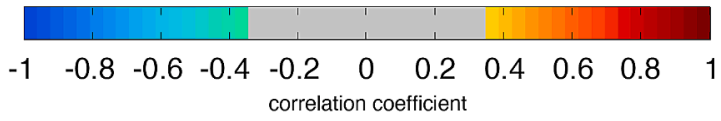

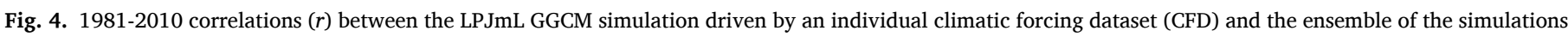

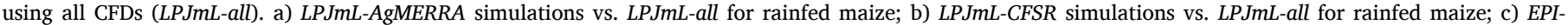

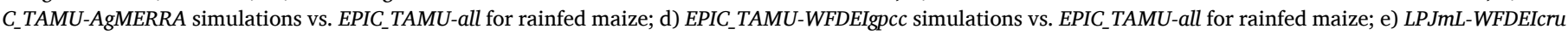

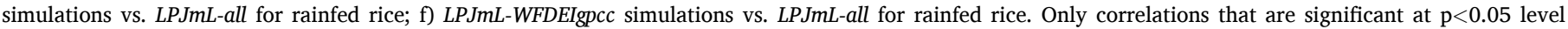
are colored. 


\section{Crop model performance with different climatic forcing datasets}

The selection of climate forcing dataset(s) for GGCM applications often depends on the availability of those inputs as well as the resources allocated to exploring CFD uncertainty and/or benefiting from CFD ensemble behaviors. In this section we examine how the selection of a CFD compares to the use of the full CFD ensemble, examining global CFD differences, performance against regional production observations, and the simulations' ability to capture national production anomalies. Differences in GGCM-CFD performance also highlight the ramifications of a given CFD's selection of an underlying reanalysis and specific biasadjustment targets and methods, as well as non-climatic configurations that reduce GGCM correlations regardless of the CFD selected.

\subsection{Global implications of CFD selection}

GGCM responses to CFD differences accumulate within any given regional farming system's growing season, with the aggregate effect being a CFD-dependent crop yield for each grid cell for each year. The temporal correlations between GGCM simulations using different CFDs therefore indicate whether the CFD selection altered the overall climate response, with low correlations indicating a fundamentally different agro-climatic relationship over the 1981-2010 period.

Fig. 4 presents the correlation between individual GGCM-CFD simulations and the median of the GGCM-all ensemble. A full intercomparison of GGCMs across all crop systems is beyond the scope of this study, so here we examine pDSSAT and LPJmL to explore potential interactions between CFD selection and GGCM utilized. LPJmL-AgMERRA correlates highly with the median of the $L P J m L$-all ensemble in much of the mid-latitudes; however, lower latitudes and many developing countries have lower correlation suggesting more CFD-based uncertainty (Fig. $4 \mathrm{a}$; ( $r>0.85$; with $\mathrm{r}>0.9$ in many high producing areas). This is consistent with the regional patterns of heightened temperature and precipitation uncertainty shown in Fig. 2. Regions of high correlations between LPJmL-AgMERRA and CFD-all cover the vast majority of maizegrowing regions including major breadbaskets in the US Midwest, Europe, China, and South America. This suggests that a single LPJmLAgMERRA simulation provides a broadly similar response to using all CFDs and then creating an ensemble median. This is not true for all CFDs, however, as can be seen for LPJmL-CFSR where lower regional correlations indicate a different pattern of interannual response imposed by that specific CFD (Fig 4b). pDSSAT generally shows a larger difference between any CFD and the CFD-all runs, as the highest-correlated a) Rainfed maize pDSSAT-AgCFSR vs. NASS

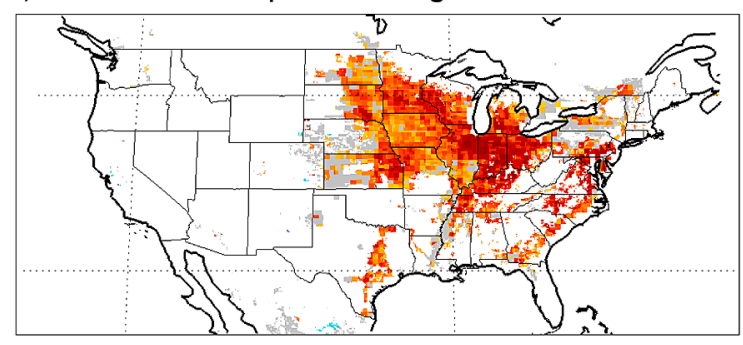

c) Rainfed maize LPJmL-WFDElgpcc vs. NASS

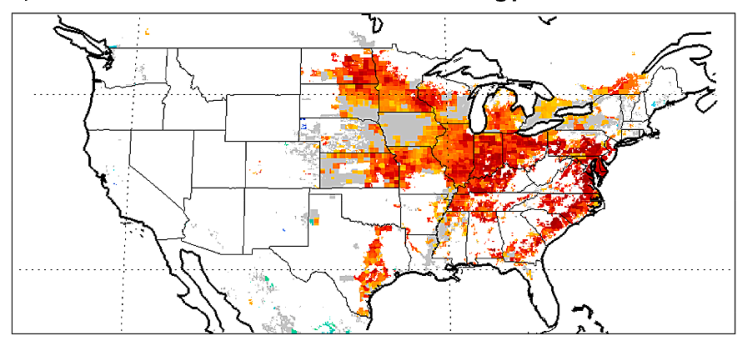

e) Rainfed maize pDSSAT-all vs. NASS

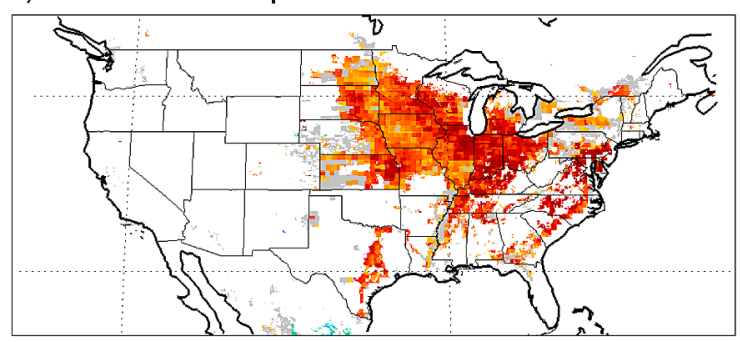

b) Rainfed maize pDSSAT-CFSR vs. NASS

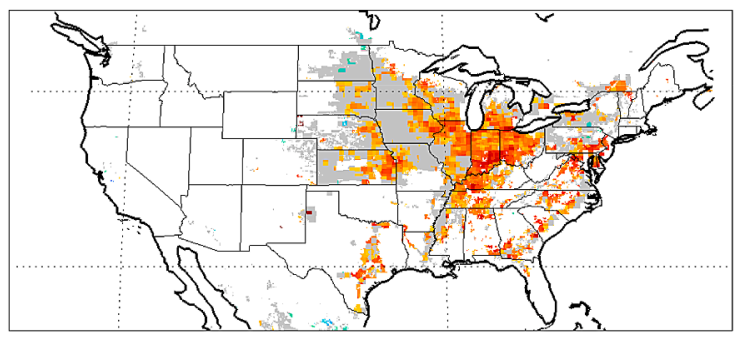

d) Rainfed maize LPJmL-ERAI vs. NASS

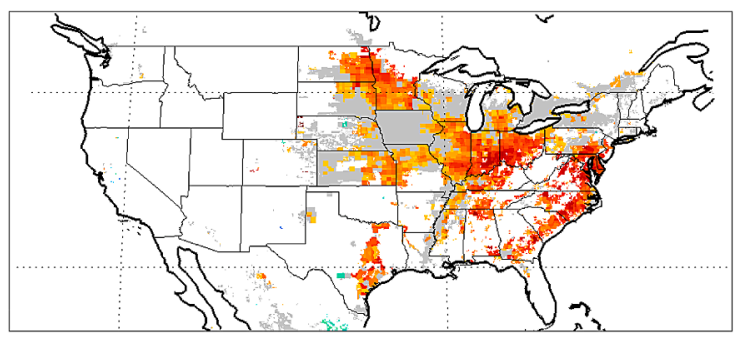

f) Rainfed maize LPJmL-all vs. NASS

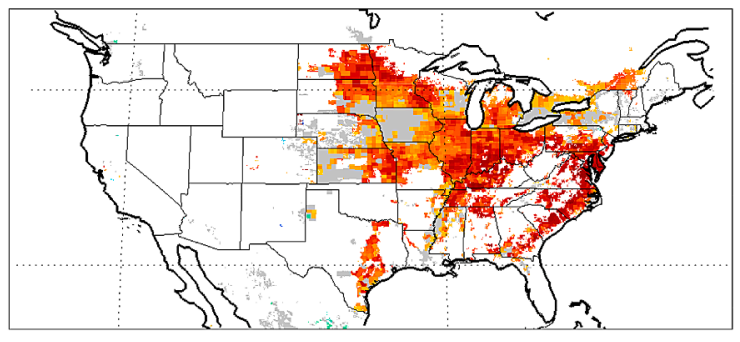

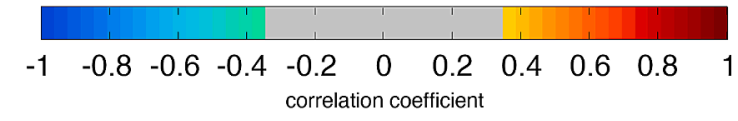

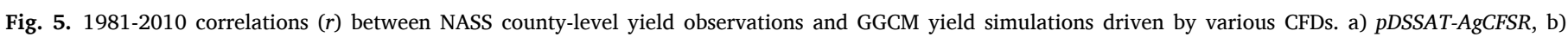

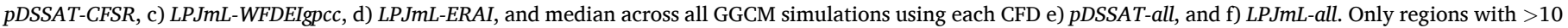
ha of planted area (You et al., 2014) are presented, and only correlations that are significant at $\mathrm{p}<0.05$ level are colored rather than gray. 
AgMERRA and WFDEIgpcc simulations still have lower correlations than were seen for LPJmL rainfed maize (Figs. 4c-d). The correlations of LPJmL-WFDEIcru and LPJmL-WFDEIgpcc vs. LPJmL-all for rainfed rice (Figs. 4e-f) show increased dependence on CFD (lower correlations) over the major rice production zones of SE Asia than were seen for maize breadbaskets in places like the US Midwest (Fig 4a). Even as WFDEIcru and WFDEIgpcc differ only in their monthly precipitation totals, LPJmL simulations driven by WFDEIgpcc follow the LPJmL-all median closely, while those driven by WFDEIcru are considerably lower in much of Brazil, the Democratic Republic of the Congo, and Madagascar.

\section{Regional implications of CFD selection}

Differences between CFDs are likely to be heightened on smaller scales, particularly when they interact with unique vulnerabilities in regional crop systems. A focus on sub-national heterogeneity is also particularly important in large countries with production regions across multiple climate zones. Fig. 5 examines sub-national features of rainfed maize simulations driven by various CFDs against the US NASS countylevel production anomalies.

The importance of bias-adjustment is underlined by comparisons between PDSSAT-AgCFSR and PDSSAT-CFSR, with the non-bias-adjusted CFSR achieving substantially lower skill over nearly all US rainfed maize regions with particularly low values over the northwest Midwest (from Missouri through North Dakota, Fig. 5a,b). Both CFDs use the same underlying CFSR reanalysis, so differences here are related to monthly mean climate, the imposition of SRB solar radiation, changes in the number of precipitation days, and adjustments to the diurnal temperature range. A similar reduction in skill is seen in LPJmL simulations using the non-bias-adjusted the ERAI reanalysis compared to the WFDEIgpcc, which also is based on ERAI daily sequences (Figs. 5c-d). In this case the swath of low-correlation simulations extending from
Nebraska to Wisconsin appears in simulations run with both CFDs, indicating a bias stemming from crop model configuration rather than the selection of CFDs. Jägermeyr and Frieler, (2018) identified this as a problem related to erroneous planting dates and cultivars that have been updated in later LPJmL configurations.

The ensemble median of pDSSAT-all and LPJmL-all are highly correlated with NASS county-level production for most of the US (Fig. 5e,f). Different regions exhibit strengths and weaknesses for each GGCM, indicating that national level production anomalies are the aggregate across regions with heterogeneous skill. In general, $P D S S A T$ AgCFSR is not substantially different from pDSSAT-all, and LPJmLWFDEIgpcc is likewise similar to LPJmL-all. This indicates that rainfed maize simulations over the US can utilize one of these CFDs without losing too much information that would otherwise be gained from the full CFD ensemble. AgCFSR, AgMERRA, WFDEIcru, and WFDEIgpcc all capture similarly high levels of correlation for LPJmL and pDSSAT rainfed maize, with CFSR and ERAI (the unadjusted reanalyses) and GRASP showing lower correlations. In some regions the best-performing CFD has higher correlations than the CFD-all median, but CFD-all excels at being near the top correlations for all regions.

\subsection{National implications of CFD selection}

Fig. 6 displays correlations between detrended FAO national production reports and simulated production (including rainfed and irrigated areas) from 1981-2010. The top 20 producing countries (20132017) for maize, wheat, rice, and soybean are shown using the CFD+ ensembles (featuring the largest common subset of GGCMs), allowing us to identify the climate-driven signal (independent of GGCM differences) and its correlation with FAO reports for each country and crop type. We also include the larger AgMERRA-all and WFDEIgpcc-all ensembles to understand the ramifications of including additional GGCMs, Ensemble+ a) Maize production correlations with FAO

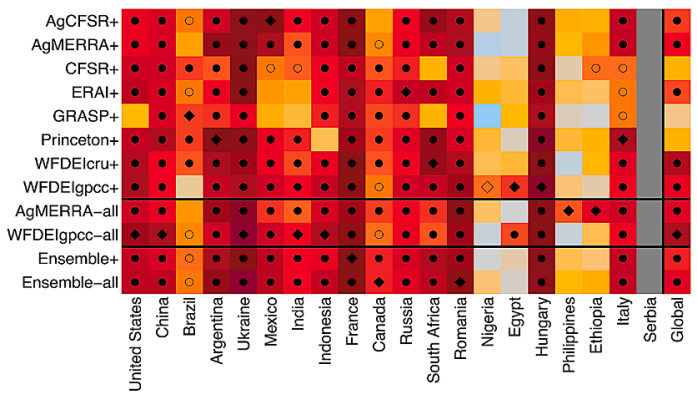

c) Rice production correlations with FAO

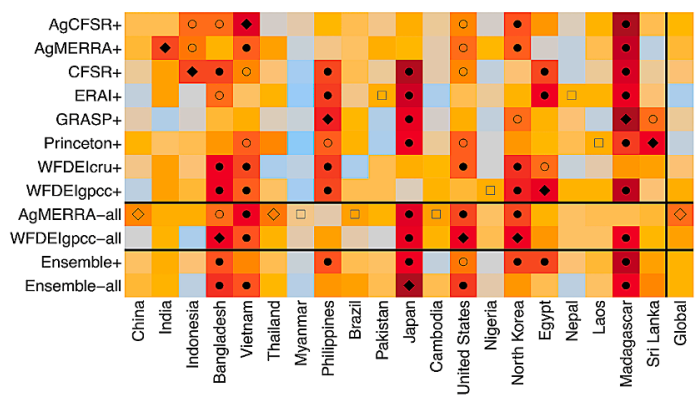

b) Wheat production correlations with FAO

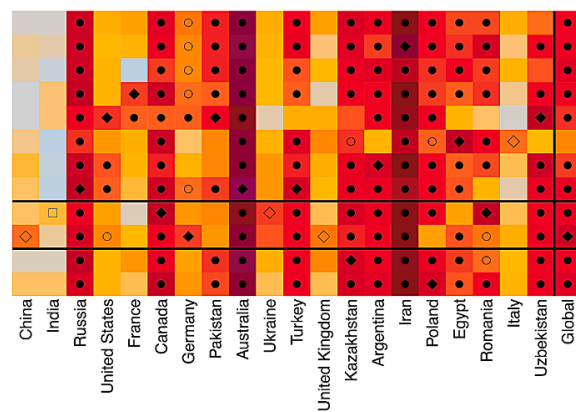

d) Soybean production correlations with FAO

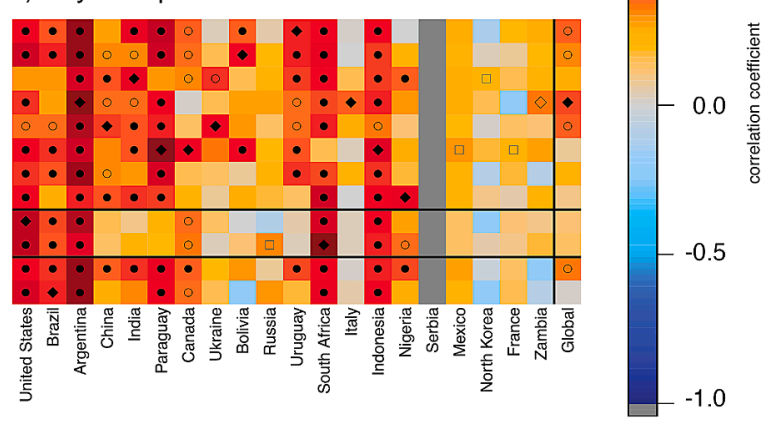

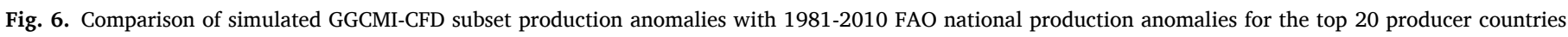

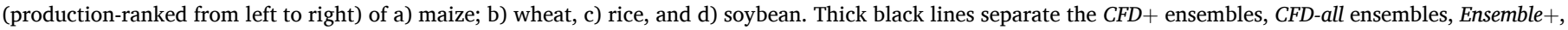

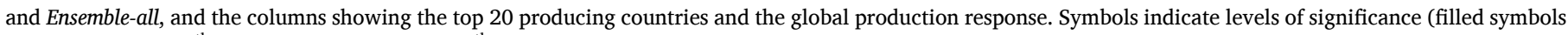

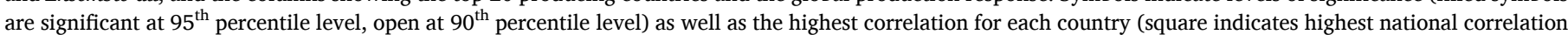

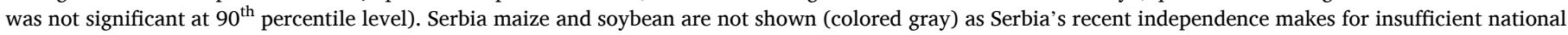

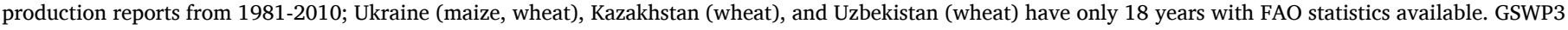
and PGFv2 are not shown as not enough GGCMs simulated these CFDs. 
to understand how an ensemble of CFDs affects performance for the common GGCM subset, and Ensemble-all for the complete GGCMI Phase 1 set of GGCM-CFD combinations (bolded configurations in Table 2). The final column in Fig. 6 shows correlations between the simulation ensembles and the total global production of each crop. Below we highlight the main features of these results, with broader interpretation provided in the discussion section that follows.

\subsubsection{National maize production anomalies}

Simulations of leading national maize producers show statistically significant positive correlations $(\mathrm{p}<0.05)$ for many of the top producing countries, indicating that the simulations are capturing a strong climatic signal within the FAO reports (Fig, 6a). The most apparent patterns in correlations come from differences between countries, whereby simulations tend to have similarly high (or low) correlations in all ensembles for a given country. This leads to stark differences between, e.g., Romania (relatively high correlations for nearly all ensembles) and Nigeria (relatively low and insignificant correlations for nearly all ensembles). Due to Serbia's independence and separation from Montenegro in 2006, only 5 years of FAO-reported production overlap with the 1981-2010 climatology, despite being a top-producer for maize and soybean in the 2013-2017 period; therefore, correlations for Serbia have been excluded from Figs. 6a,d.

Bias-adjusted CFDs tend to produce higher correlations in Fig. 6 than the raw reanalyses (CFSR and ERAI) and the GRASP dataset that adjusted according to fixed parameters determined from a previous climatological period. AgMERRA + and WFDEIgpcc + are typically among the highest $C F D+$ correlations. The addition of GGCMs for AgMERRA-all and WFDEIgpcc-all did not show clear benefits over the corresponding AgMERRA + and WFDEIgpcc-all (correlations improved in 10 and 8 of the 19 countries, respectively) This is similar to expectations given that there is a reduced benefit when adding to an ensemble that already has 6 GGCMs unless a unique simulation feature is added, which seems to be the case in Brazil given higher correlations for both although the additional models lower correlations in Nigeria. The ensemble of the GGCM subset and CFDs in Ensemble + is nearly identical to the full Ensemble-all, with the latter showing higher correlations in 13 of 19 maize countries.

Several ensembles produce significant correlations with FAO global production reports. These include AgCFSR+, AgMERRA+, ERAI+, WFDEIcru+, WFDEIgpcc+, AgMERRA-all, WFDEIgpcc-all, Ensemble+, and Ensemble-all. WFDEIgpcc-all has the highest global correlation $(\mathrm{r}=0.682)$ as well the highest correlation out of all ensembles in 5 of the top 8 maize production countries. AgMERRA-all correlations are significant for 16 of the 19 countries, with significantly higher skill than any other ensemble in the Philippines and Ethiopia. These results highlight the potential for broader GGCM application for national and global maize production decision making. Ensemble-all had an increase in global correlation $(+0.094)$ compared to Ensemble + .

\subsubsection{National wheat production anomalies}

Wheat simulations generally have lower correlations than were seen for maize, indicating a comparatively smaller agroclimatic signal or common biases in the structure or configuration of wheat models (Fig, $6 \mathrm{~b})$. Correlation levels are once again highly related to the various nations, with simulation ensembles of the top two producing countries, China and India, not significantly correlated to their FAO production statistics (with the exception of WFDEIgpcc-all in China) even as positive correlations dominate most of the other countries. This may be due, in part, to the large area devoted to irrigated wheat in these countries, which lowers the response to drought hazards and therefore overall climate sensitivity. Diseases are also not included in GGCM simulations but can play a major role in wheat breadbaskets (Savary et al., 2019). Intensified systems in the United States, France, Germany, the United Kingdom, and the Ukraine also have mostly insignificant correlations even as weather data are likely of good quality, indicating a large role of irrigation and perhaps a muddled signal in grid cells where both spring wheat and winter wheat is present. GGCMI Phase 1 simulations only ran one wheat season per grid cell, which can miss second season production anomalies and underrepresent vernalization requirement effects. Subsequent GGCMI phases have conducted separate simulations for winter and spring wheat in order to better capture production in regions where both systems are prominent (Franke et al., 2020, 2019; Jägermeyr et al., 2020). Simulations capture high correlations indicating a strong climate response for Australian wheat, which is dominated by rainfed winter wheat demonstrating a strong precipitation response (Fig 3e). Simulated wheat in European countries showed little response to growing season temperature, precipitation, and solar radiation in Fig. 3, however; which is consistent with relatively low national-level correlations to FAOstat.

The bias-adjusted CFDs largely outperform the raw reanalyses and GRASP for most wheat countries. WFDEIgpcc-all increases correlations for China and Germany in comparison to WFDEIgpcc + likely due to high correlations in at least one of the added GGCMs, although a decrease in correlation is seen for Poland and the United States. AgMERRA-all similarly improves upon AgMERRA + correlations in Canada and the Ukraine. Overall, AgMERRA-all and WFDEIgpcc-all both improved correlations in half of the countries. Although the Ensemble + and Ensembleall have higher wheat correlations in Pakistan, there is otherwise little difference between AgMERRA+, WFDEIgpcc+, Ensemble+, and Ensembleall which have significant correlations in 13, 13, 12, and 12 of the top 20 wheat producing countries, respectively. Global wheat anomalies are fairly consistently and significantly simulated by all ensembles, with WFDEIgpcc-all producing the highest global correlation $(\mathrm{r}=0.603)$ aided by relatively strong performance in China, Germany, and the United Kingdom.

\subsubsection{National rice production anomalies}

Rice simulations have the lowest FAO correlations of the four simulated crops (Fig. 6c). Significant correlations are highest for Japan, which Ray et al. (2015) also noted as being strongly driven by temperature variation, as is also evident in Fig. 3. Significant correlations are also broadly seen for Bangladesh, Vietnam, Philippines, United States, North Korea, Egypt and Madagascar, but there are no clear patterns identifying geographic regions with cohesively high or low correlations.

Rice is largely irrigated across top producing countries, with a smaller weather signal in interannual yield fluctuations. Yet, insignificant rice correlations in many countries could be an indication of incomplete FAO data, inaccurate CFDs, poor GGCM simulation, or a realistically small agroclimatic response that may reflect regional farming systems or limiting factors beyond direct climate conditions. Ray et al. (2015) and identified that interannual rice variability was driven less by climate than were maize, wheat and soybean, which may also reflect the substantial influence of geopolitical events and socioeconomic limitations in major rice producing countries over the 1981-2010 period that would influence FAO production data. Iizumi et al., (2018) similarly found weak attribution of climate change impacts in long-term rice trends. The simulation ensemble demonstrated only weak response to growing-season mean temperature and precipitation over the major rice baskets of East, South, and Southeast Asia (Fig. 3g-i). These are among the only major breadbaskets in the Tropics, which tend to have lower interannual variability of mean temperature and total precipitation than mid-latitude breadbaskets. These rice areas also have more uncertain climate information (Fig. 2) and have a higher proportion of total production coming from heterogeneous farming systems that are difficult to configure within GGCMs. GGCM configurations may also simulate upland (non-flooded) rice systems in areas where rice is grown in paddies (flooded), and only contain a maximum of one rainfed and one irrigated season even as it is common for some rice-growing areas to have two or three seasons in a given year (e.g., the aus, aman, and boro seasons in Bangladesh). Major flood events that can destroy large rice harvests in the Mekong, Indus, Ganges, and other river basins, as well as the influence of large hurricanes and typhoons, are also not resolved by crop models despite being substantial climate disasters 
(Lesk et al., 2016).

There is no substantial benefit in bias adjustment for national rice applications, with no clear differences in correlation levels between the raw reanalyses (CFSR, ERAI), GRASP, and the other CFDs adjusted to match monthly observations. The bias-adjustments within AgCFSR+, AgMERRA+, WFDEIcru+, and WFDEIgpcc + (but not Princeton+) lower correlations in Japan, although high correlations are seen when all GGCMs are included in AgMERRA-all and WFDEIgpcc-all. The top two rice production countries, China and India, are only significantly simulated in the AgMERRA + and AgMERRA-all ensembles. Compared to $A g M E R R A+$ and WFDEIgpcc+, respectively, the additional GGCMs increase correlations for many countries in AgMERRA-all (notably Japan, Vietnam, the Philippines, the United States, and China but not India or Madagascar) and WFDEIgpcc-all (notably Japan and the United States but not Egypt or the Philippines). While the signal was mixed for WFDEIgpcc-all, 14 out of 20 AgMERRA-all country correlations were higher than AgMERRA+, including 10 that increased by $\geq 0.1$ compared to only 2 where correlations dropped by $\geq 0.1$. Ensemble + and Ensembleall capture many of the stronger correlations from rice simulations, but both also see reductions in some country correlations (e.g., Ensemble + in Vietnam and Ensemble-all in North Korea). The highest global correlation is found in AgMERRA-all ( $\mathrm{r}=0.347$ ), aided by higher correlations in China, Vietnam and Thailand, with other ensembles unable to capture significant correlations with global rice production.

\subsubsection{National soybean production anomalies}

Soybean simulations have higher correlations overall than rice, with higher producing countries tending to have higher correlations and the lower producing countries tending to not be significantly correlated (Fig. 6d). The highest correlations are associated with the United States, Brazil, Argentina, Paraguay, South Africa and Indonesia, while Ukraine, Bolivia Russia are top-10 high-producing countries where relatively few ensembles capture a significant interannual signal.

The bias-adjusted CFDs have a larger number of significant correlations than the raw reanalysis (CFSR+ and ERAI+) and GRASP+ ensembles, which signifies a benefit to bias adjustment particularly in the highest producing countries. AgMERRA-all and WFDEIgpcc-all have slightly reduced correlations compared to AgMERRA + (lower in 13 out of 19 countries) and WFDEIgpcc + (lower in 11 out of 19 countries) as the inclusion of additional GGCMs reduces the captured climate signal particularly for China, India, Paraguay, and Uruguay. Ensemble + and AgMERRA+ produce a significant correlation in each of the top 7 countries, and Ensemble-all loses significant signals in China, India, and Uruguay.

Global correlations are generally positive but weaker than those seen for maize and wheat. Significant correlations are captured by $A g C F S R+$, AgMERRA+, ERAI+ (top correlation at $\mathrm{r}=0.416$ ), GRASP+ and Ensemble+. The low global correlation compared to the top countries' high correlation is surprising, possibly indicating inter-breadbasket anticorrelations that act to offset a larger global signal. Ensemble-all global correlation is 0.313 lower than for Ensemble+, indicating a substantial loss of signal within the additional CFD/GGCM combinations.

\section{Discussion}

The analyses above demonstrate many ways that the selection of CFD strongly influences regional crop production simulations. Although it is not practical to analyze every combination of specific nations, cropping systems and crop model ensemble sets in this manuscript, the examples, approaches, supplementary material, and open data access of the GGCMI Phase 1 dataset provide a roadmap for further analysis. The extent of CFD influence depends on differences between CFD characteristics, crop models' biophysical responses to these differences, attributes of national and global production for each crop species, and the use of multi-GGCM and multi-CFD ensembles. Key findings are discussed below, with additional uncertainties in climate and crop model information described in Supplemental Material S8.

Regional differences in climate information and responses. CFDs differ most strongly in regions where in situ observations are sparse, inconsistent or incomplete (Fig. 2), and can have nearly global differences in distributional or extreme characteristics (Figs. 1 and S.3-5). Regional cropping system models have different fundamental responses to climate variability in ways that can make them more sensitive to CFD differences (Fig. 3). The selection of CFDs is therefore most influential in regions where agricultural systems respond strongly to a climatic variable with strong observational uncertainties. Further analysis, and indeed GGCM development, is required to investigate cropping system response to variables beyond the growing season mean climate indices, as considerable variance is likely from sub-seasonal patterns, acute heat, drought and flood extremes, severe storms, and connected impacts from sequential or compound hazards (Ben-Ari et al., 2018; Grotjahn, 2020; Li et al., 2019; Raymond et al., 2020; Schewe et al., 2019). Fundamental climate responses also help prioritize observational network and agricultural resilience investments even as interannual response is not always a clear predictor of long-term climate change risks (Ruane et al., 2016).

GGCM/CFD abilities to capture observed interannual variance: The selection of CFDs is only able to influence a fraction of interannual production variations. GGCMI results (e.g., Fig. 6) are broadly consistent with the findings of Ray et al. (2015), who found that climate variation explains only about one third of global observed yield variability, with upwards of $60 \%$ of variation explained in some highly intensified breadbaskets and lower fundamental climate responses for rice than maize, wheat or soybean. Lower correlations may also be related to non-representative model configurations, including incorrect planted area fractions which can change from year to year, growing season dates and cultivars (Jägermeyr and Frieler, 2018), the presence of multiple growing seasons (e.g., short and long rains), multi-cropping, sub-grid scale heterogeneity in climate and crop systems, soil types and textures, and alternative irrigation management strategies (Hoffmann et al., 2016; Lopez et al., 2017). High correlations between FAO data and simulation outputs are therefore indicative of strong climate forcing in national production anomalies and an ability of the GGCMs (driven by CFDs) to capture those anomalies. In some cases the GGCMI climate-driven ensemble captures a higher proportion of the FAO production variability that was evident in Ray et al., (2015), including for maize in Mexico, wheat in Iran, rice in Madagascar, and soybean in Paraguay.

Some crop species and countries are not as clearly limited by climate. GGCMI simulations generally produced the highest FAO correlations for maize, followed by wheat, soy, and rice. For each species there were countries with high and low correlations. High correlations countries tend to feature some combination of large-scale intensified farming, mid-latitude climates, less uncertainty in climate and farm configuration information, and consolidated production regions. Lower correlation countries tend to have a relatively large proportion of heterogeneous and small-holder farming systems, are situated in tropical regions with lower interannual variability, and lie in areas with more uncertain climate anomalies and field data (Fig. 2). We would expect these process-based crop models to be more climate-limited than observations, as factors not included in the models reduce the coherence with the seasonal climate signal (e.g., sociopolitical events, labor or machine shortages, river floods, pests and diseases) (Ray et al., 2015; van Ittersum et al., 2016). Many of these non-climatic impact factors are more widespread in developing countries than in intensified agricultural regions of developed countries (van Bussel et al., 2015).

Overall performance of CFDs. This study further confirms the utility of climatic forcing datasets for agricultural applications (Toreti et al., 2019) and elucidates ways that CFD differences can affect crop model simulations (Figs. 4, 5, 6). Normalized anomalies between CFDs are larger for precipitation than for temperature, and differences between CFDs are larger for distributional characteristics and extreme events 
than for mean response (Figs. 1,2). The use of bias adjustment (AgCFSR vs. CFSR and WFDEI vs. ERAI) improved crop model simulation in many regions and countries, while the sequence of sub-monthly weather patterns (AgCFSR vs. AgMERRA) had a smaller impact (Figs. 5,6). The selection of large-scale precipitation datasets (WFDEIgpcc vs. GPCCcru) did not have a substantial overall effect on performance. These conclusions for complex biophysical models are consistent with those found by (Parkes et al., 2019) for empirical models. We advise those planning crop model applications for a given country and crop species to examine Fig. 6 to ensure that their CFD is associated with high correlations against FAO production variability.

Effects of model ensemble statistics. GGCMI uses the 1980-2010 period to benchmark the performance of global gridded crop models (Müller et al., 2017), and this study has further demonstrated the utility of this period to elucidate the strengths and weaknesses of various GGCM/CFD ensembles through comparison against FAO anomalies. Comparing across minimal multi-GGCM ensembles for each $C F D+$, a major finding is that the difference between countries > difference between CFDs > difference between $C F D+$ and $C F D$-all ensembles (the effect of more GGCMs on top of the multi-GGCM ensemble) > difference between Ensemble-all and Ensemble+ ensembles (the effect of adding further GGCM/CFD combinations on top of the multi-GGCM/multi-CFD Ensemble+). Differences between countries emphasizes the importance of improving data collection for climate, soils, cultivars, and field management which can vary widely by nation. Differences between CFDs can be substantial in some parts of the world (Fig. 2), but our overall finding is that the bias-adjusted datasets (e.g., AgMERRA and WFDEIgpcc) capture the bulk of the signal captured in the GGCMI ensemble. In light of previous AgMIP studies on the benefits of small multi-crop model ensembles (Wallach et al., 2016), we recommend that resources are likely better focused on additional configuration information and the inclusion of a multi-GGCM ensemble (3-7 models) before conducting a multi-CFD ensemble. Here the maize, wheat, and soybean CFD + ensembles had 7 GGCMs (5 for rice), and the further addition of GGCMs was not consistently helpful to the extent that would justify investment for larger GGCM ensembles (Figs. 2, 3, S.2). Given that Ensemble + has 56 GGCM/CFD combinations for maize, the lack of clear benefit from the full 91 GGCM/CFD combination Ensemble-all underscores that the full GGCMI ensemble is not typically needed for practical application.

A number of agricultural system applications stand to benefit from more accurate climate observation, modeling, bias-adjustment, and methods to merge these into CFDs, including seasonal forecasting (Schauberger et al., 2017), disaster preparedness (Cottrell et al., 2019; Jägermeyr et al., 2020; Lunt et al., 2016), climate change resilience (Franke et al., 2019; Hasegawa et al., 2018; Rosenzweig et al., 2014; Ruane et al., 2018b; Zhao et al., 2017), and the development of more robust and sustainable markets and farming systems (Snyder et al., 2019; Valdivia et al., 2015). A new generation of CFDs are now possible given updated reanalyses (Gelaro et al., 2017; Hersbach et al., 2019) and observational products (Funk et al., 2015; Lange, 2019c), which will enable further crop modeling applications (e.g., Iizumi et al., 2017; Lange, 2019b; Lange, 2019c). CFD characteristics also propagate into climate scenarios that use the CFD as a bias-adjustment target, so CFD deviations presented in Fig. 1 and Figures S.3-5 may help explain differences in regional projections among studies. We include a similar comparison of the W5E5 dataset to the GGCMI CFD ensemble in Supplemental Figure S.5 given its application in forthcoming ISIMIP Phase 3 simulations. Improvements in CFDs, and the selection of a CFD particularly suited for a given regional farming system, are therefore important elements of a crop model application even as they are a limited element of broader application improvement efforts. Further opportunities for model development and application motivated by this study are described in Supplementary Material S9.

\section{Declaration of Competing Interest}

Ruane et al. Strong regional influence of climatic forcing datasets on global crop model ensembles

The authors declare that they have no known competing financial interests or personal relationships that could have appeared to influence the work reported in this paper.

\section{Acknowledgements}

Funding: Support for this study was provided by NASA NNX16AK38G (INCA), and the NASA Earth Sciences Directorate/GISS Climate Impacts Group funding. DD acknowledges the HPC Cluster supported by the Research and Specialist Computing Support service at the University of East Anglia for running PEGASUS. TAMP and AA acknowledge support from European Union FP7 Grant LUC4C (Grant 603542), and the Helmholtz Association in its ATMO Programme. ES acknowledges financial support from the UncertProp project (KR16AC0K13332) funded by the Austrian Climate and Energy Fund within the Austrian Climate Research Programme. TI acknowledges the Environment Research and Technology Development Fund (JPMEERF20202005) of the Environmental Restoration and Conservation Agency. Helpful initial analyses and insights were provided by Monica Morales, Nicholas Hudson, and Kevin Schwarzwald at the Columbia University Center for Climate Systems Research/NASA GISS. Figure preparation assisted by Maria Dombrov.

\section{Supplementary materials}

Supplementary material associated with this article can be found, in the online version, at doi:10.1016/j.agrformet.2020.108313.

\section{References}

Antle, J.M., Valdivia, R.O., Boote, K.J., Janssen, S., Jones, J.W., Porter, C.H., Rosenzweig, C., Ruane, A.C., Thorburn, P.J., 2015. AgMIP's Transdisciplinary Agricultural Systems Approach to Regional Integrated Assessment of Climate Impacts, Vulnerability, and Adaptation. Handb. Clim. Chang. Agroecosystems, pp. 27-44. https://doi.org/10.1142/9781783265640_0002.

Bassu, S., Brisson, N., Durand, J.L., Boote, K., Lizaso, J., Jones, J.W., Rosenzweig, C., Ruane, A.C., Adam, M., Baron, C., Basso, B., Biernath, C., Boogaard, H., Conijn, S., Corbeels, M., Deryng, D., De Sanctis, G., Gayler, S., Grassini, P., Hatfield, J., Hoek, S., Izaurralde, C., Jongschaap, R., Kemanian, A.R., Kersebaum, K.C., Kim, S.H.,

Kumar, N.S., Makowski, D., Müller, C., Nendel, C., Priesack, E., Pravia, M.V., Sau, F., Shcherbak, I., Tao, F., Teixeira, E., Timlin, D., Waha, K., 2014. How do various maize crop models vary in their responses to climate change factors? Glob. Chang. Biol. 20, 2301-2320. https://doi.org/10.1111/gcb.12520.

Ben-Ari, T., Boé, J., Ciais, P., Lecerf, R., Van Der Velde, M., Makowski, D., 2018. Causes and implications of the unforeseen 2016 extreme yield loss in the breadbasket of France. Nat. Commun. 9, 1-10. https://doi.org/10.1038/s41467-018-04087-x.

Compo, G.P., Whitaker, J.S., Sardeshmukh, P.D., Matsui, N., Allan, R.J., Yin, X., Gleason, B.E., Vose, R.S., Rutledge, G., Bessemoulin, P., Brönnimann, S., Brunet, M., Crouthamel, R.I., Grant, A.N., Groisman, P.Y., Jones, P.D., Kruk, M.C., Kruger, A.C., Marshall, G.J., Maugeri, M., Mok, H.Y., Nordli, Ø., Ross, T.F., Trigo, R.M., Wang, X. L., Woodruff, S.D., Worley, S.J., 2011. The Twentieth Century Reanalysis Project. Q. J. R. Meteorol. Soc. 137, 1-28. https://doi.org/10.1002/qj.776.

Cottrell, R.S., Nash, K.L., Halpern, B.S., Remenyi, T.A., Corney, S.P., Fleming, A., Fulton, E.A., Hornborg, S., Johne, A., Watson, R.A., Blanchard, J.L., 2019. Food production shocks across land and sea. Nat. Sustain. 2, 130-137. https://doi.org/ 10.1038/s41893-018-0210-1.

Dee, D.P., Uppala, S.M., Simmons, A.J., Berrisford, P., Poli, P., Kobayashi, S., Andrae, U., Balmaseda, M.A., Balsamo, G., Bauer, P., Bechtold, P., Beljaars, A.C.M., van de Berg, L., Bidlot, J., Bormann, N., Delsol, C., Dragani, R., Fuentes, M., Geer, A.J., Haimberger, L., Healy, S.B., Hersbach, H., Hólm, E.V., Isaksen, L., Kållberg, P., Köhler, M., Matricardi, M., Mcnally, A.P., Monge-Sanz, B.M., Morcrette, J.J., Park, B. K., Peubey, C., de Rosnay, P., Tavolato, C., Thépaut, J.N., Vitart, F., 2011. The ERAInterim reanalysis: Configuration and performance of the data assimilation system. Q. J. R. Meteorol. Soc. 137, 553-597. https://doi.org/10.1002/qj.828.

Deryng, D., Conway, D., Ramankutty, N., Price, J., Warren, R., 2014. Global crop yield response to extreme heat stress under multiple climate change futures. Environ. Res. Lett. 9, 034011 https://doi.org/10.1088/1748-9326/9/3/034011.

Dirmeyer, P.A., Gao, X., Zhao, M., Guo, Z., Oki, T., Hanasaki, N., 2006. GSWP-2: Multimodel analysis and implications for our perception of the land surface. Bull. Am. Meteorol. Soc. 87, 1381-1397. https://doi.org/10.1175/BAMS-87-10-1381.

Elliott, J., Müller, C., Deryng, D., Chryssanthacopoulos, J., Boote, K.J., Büchner, M., Foster, I., Glotter, M., Heinke, J., Iizumi, T., Izaurralde, R.C., Mueller, N.D., Ray, D. 
K., Rosenzweig, C., Ruane, A.C., Sheffield, J., 2015. The Global Gridded Crop Model Intercomparison: data and modeling protocols for Phase 1 (v1.0), Geoscientific Model Development. Copernicus GmbH. https://doi.org/10.5194/gmd-8-261-2015. European Centre for Medium-Range Weather Forecasts, 2009. ERA-Interim Project. Research Data Archive at the National Center for Atmospheric Research. Computational and Information Systems Laboratory, Boulder, CO. https://doi.org/ 10.5065/D6CR5RD9.

Famien, A.M., Janicot, S., Ochou, A.D., Vrac, M., Defrance, D., Sultan, B., Noël, T., 2018. A bias-corrected CMIP5 dataset for Africa using the CDF-t method - a contribution to agricultural impact studies. Earth Syst. Dyn. 9, 313-338. https://doi.org/10.5194/ esd-9-313-2018.

Fleisher, D.H., Condori, B., Quiroz, R., Alva, A., Asseng, S., Barreda, C., Bindi, M., Boote, K.J., Ferrise, R., Franke, A.C., Govindakrishnan, P.M., Harahagazwe, D. Hoogenboom, G., Naresh Kumar, S., Merante, P., Nendel, C., Olesen, J.E., Parker, P. S., Raes, D., Raymundo, R., Ruane, A.C., Stockle, C., Supit, I., Vanuytrecht, E., Wolf, J., Woli, P., 2017. A potato model intercomparison across varying climates and productivity levels. Glob. Chang. Biol. 23, 1258-1281. https://doi.org/10.1111/ gcb.13411.

Folberth, C., Elliott, J., Müller, C., Balkovič, J., Chryssanthacopoulos, J., Izaurralde, R.C., Jones, C.D., Khabarov, N., Liu, W., Reddy, A., Schmid, E., Skalský, R., Yang, H., Arneth, A., Ciais, P., Deryng, D., Lawrence, P.J., Olin, S., Pugh, T.A.M., Ruane, A.C., Wang, X., 2019. Parameterization-induced uncertainties and impacts of crop management harmonization in a global gridded crop model ensemble. PLoS ONE. https://doi.org/10.1371/journal.pone.0221862.

Franke, J., Müller, C., Elliott, J., Ruane, A., Jagermeyr, J., Balkovic, J., Ciais, P., Dury, M., Falloon, P., Folberth, C., Francois, L., Hank, T., Hoffmann, M., Jacquemin, I., Jones, C., Khabarov, N., Koch, M., Li, M., Liu, W., Olin, S., Phillips, M. Pugh, T.A., Reddy, A., Wang, X., Williams, K., Zabel, F., Moyer, E., 2019. The GGCMI Phase II experiment: global gridded crop model simulations under uniform changes in $\mathrm{CO} 2$, temperature, water, and nitrogen levels (protocol version 1.0). Geosci. Model Dev. Discuss, pp. 1-30. https://doi.org/10.5194/gmd-2019-237.

Franke, J., Müller, C., Elliott, J., Ruane, A.C., Jagermeyr, J., Snyder, A., Dury, M., Falloon, P., Folberth, C., Francois, L., Hank, T., Izaurralde, R.C., Jacquemin, I., Jones, C., Li, M., Liu, W., Olin, S., Phillips, M.M., Pugh, T.A.M., Reddy, A.D., Williams, K., Wang, Z., Zabel, F., Moyer, E.J., 2020. The GGCMI phase II emulators : global gridded crop model responses to changes in $\mathrm{CO} 2$, temperature, water, and nitrogen. Geosci. Model Dev. Discuss. https://doi.org/10.5194/gmd-2019-365

Fritz, S., See, L., McCallum, I., You, L., Bun, A., Moltchanova, E., Duerauer, M., Albrecht, F., Schill, C., Perger, C., Havlik, P., Mosnier, A., Thornton, P., WoodSichra, U., Herrero, M., Becker-Reshef, I., Justice, C., Hansen, M., Gong, P., Abdel Aziz, S., Cipriani, A., Cumani, R., Cecchi, G., Conchedda, G., Ferreira, S., Gomez, A., Haffani, M., Kayitakire, F., Malanding, J., Mueller, R., Newby, T., Nonguierma, A., Olusegun, A., Ortner, S., Rajak, D.R., Rocha, J., Schepaschenko, D.,

Schepaschenko, M., Terekhov, A., Tiangwa, A., Vancutsem, C., Vintrou, E. Wenbin, W., van der Velde, M., Dunwoody, A., Kraxner, F., Obersteiner, M., 2015 Mapping global cropland and field size. Glob. Chang. Biol. 21, 1980-1992. https:// doi.org/10.1111/gcb.12838.

Fuchs, T., 2009. GPCC annual report for year 2008: Development of the GPCC data base and analysis products. DWD Rep.

Funk, C., Peterson, P., Landsfeld, M., Pedreros, D., Verdin, J., Shukla, S., Husak, G., Rowland, J., Harrison, L., Hoell, A., Michaelsen, J., 2015. The climate hazards infrared precipitation with stations - A new environmental record for monitoring extremes. Sci. Data 2, 1-21. https://doi.org/10.1038/sdata.2015.66.

Galmarini, S., Cannon, A.J., Ceglar, A., Christensen, O.B., de Noblet-Ducoudré, N., Dentener, F., Doblas-Reyes, F.J., Dosio, A., Gutierrez, J.M., Iturbide, M., Jury, M., Lange, S., Loukos, H., Maiorano, A., Maraun, D., McGinnis, S., Nikulin, G., Riccio, A., Sanchez, E., Solazzo, E., Toreti, A., Vrac, M., Zampieri, M., 2019. Adjusting climate model bias for agricultural impact assessment: How to cut the mustard. Clim. Serv. 13, 65-69. https://doi.org/10.1016/J.CLISER.2019.01.004.

Gelaro, R., McCarty, W., Suárez, M.J., Todling, R., Molod, A., Takacs, L., Randles, C.A., Darmenov, A., Bosilovich, M.G., Reichle, R., Wargan, K., Coy, L., Cullather, R., Draper, C., Akella, S., Buchard, V., Conaty, A., da Silva, A.M., Gu, W., Kim, G.K., Koster, R., Lucchesi, R., Merkova, D., Nielsen, J.E., Partyka, G., Pawson, S., Putman, W., Rienecker, M., Schubert, S.D., Sienkiewicz, M., Zhao, B., 2017. The modern-era retrospective analysis for research and applications, version 2 (MERRA2). J. Clim. 30, 5419-5454. https://doi.org/10.1175/JCLI-D-16-0758.1.

Grotjahn, R., 2020. Weather extremes that impact various agricultural commodities. In: Castillo, F., Wehner, M., Stone, D. (Eds.), Extreme Events and Climate Change: A Multidisciplinary 28 Approach. John Wiley \& Sons, Inc. for American Geophysical Union p. (in press).

Harris, I., Jones, P.D., Osborn, T.J., Lister, D.H., 2014. Updated high-resolution grids of monthly climatic observations - the CRU TS3.10 Dataset. Int. J. Climatol. 34, 623-642. https://doi.org/10.1002/joc.3711.

Hasegawa, T., Fujimori, S., Havlík, P., Valin, H., Bodirsky, B.L., Doelman, J.C., Fellmann, T., Kyle, P., Koopman, J.F.L., Lotze-Campen, H., Mason-D’Croz, D., Ochi, Y., Pérez Domínguez, I., Stehfest, E., Sulser, T.B., Tabeau, A., Takahashi, K., Takakura, J., van Meijl, H., van Zeist, W.J., Wiebe, K., Witzke, P., 2018. Risk of increased food insecurity under stringent global climate change mitigation policy. Nat. Clim. Chang. https://doi.org/10.1038/s41558-018-0230-x.

Hatfield, J.L., Prueger, J.H., 2015. Temperature extremes: Effect on plant growth and development. Weather Clim. Extrem. 10, 4-10. https://doi.org/10.1016/j. wace.2015.08.001.

Hersbach, H., Bell, B., Berrisford, P., Horányi, A., Sabater, J.M., Nicolas, J., Radu, R., Schepers, D., Simmons, A., Soci, C., Dee, D., 2019. Global reanalysis: goodbye ERAInterim, hello ERA5. ECMWF Newsl. 17-24. 10.21957/vf291hehd7.
Hoffmann, H., Zhao, G., Asseng, S., Bindi, M., Biernath, C., Constantin, J., Coucheney, E., Dechow, R., Doro, L., Eckersten, H., Gaiser, T., Grosz, B., Heinlein, F., Kassie, B.T., Kersebaum, K.-C., Klein, C., Kuhnert, M., Lewan, E., Moriondo, M., Nendel, C., Priesack, E., Raynal, H., Roggero, P.P., Rötter, R.P., Siebert, S., Specka, X., Tao, F., Teixeira, E., Trombi, G., Wallach, D., Weihermüller, L., Yeluripati, J., Ewert, F., 2016. Impact of Spatial Soil and Climate Input Data Aggregation on Regional Yield Simulations. PLoS One 11. https://doi.org/10.1371/journal.pone.0151782.

Iizumi, T., Okada, M., Yokozawza, M., 2014. A meteorological forcing data set for global crop modeling: Development, evaluation, and intercomparison. J. Geophys. Res. Atmos. 119, 363-384. https://doi.org/10.1002/2013JD020130.

Iizumi, T., Shiogama, H., Imada, Y., Hanasaki, N., Takikawa, H., Nishimori, M., 2018. Crop production losses associated with anthropogenic climate change for 1981-2010 compared with preindustrial levels. Int. J. Climatol. 38, 5405-5417. https://doi.org/ $10.1002 /$ joc. 5818.

Iizumi, T., Takikawa, H., Hirabayashi, Y., Hanasaki, N., Nishimori, M., 2017. Contributions of different bias-correction methods and reference meteorological forcing data sets to uncertainty in projected temperature and precipitation extremes. J. Geophys. Res. 122, 7800-7819. https://doi.org/10.1002/2017JD026613.

Jägermeyr, J., Frieler, K., 2018. Spatial variations in crop growing seasons pivotal to reproduce global fluctuations in maize and wheat yields. Sci. Adv. 4 https://doi.org/ 10.1126/sciadv.aat4517.

Jägermeyr, J., Robock, A., Elliott, J., Müller, C., Xia, L., Khabarov, N., Folberth, C., Schmid, E., Liu, W., Zabel, F., Rabin, S., Puma, M.J., Heslin, A.C., Franke, J., Foster, I., Asseng, S., Bardeen, C.G., Toon, O.B., Rosenzweig, C., 2020. A regional nuclear conflict would compromise global food security. PNAS (in press).

Kalnay, E., Kanamitsu, M., Kistler, R., Collins, W., Deaven, D., Gandin, L., Iredell, M., Saha, S., White, G., Woollen, J., Zhu, Y., Chelliah, M., Ebisuzaki, W., Higgins, W. Janowiak, J., Mo, K.C., Ropelewski, C., Wang, J., Leetmaa, A., Reynolds, R., Jenne, R., Joseph, D., 1996. The NCEP/NCAR 40-year reanalysis project. Bull. Am. Meteorol. Soc. 77, 437-471.doi:10.1175/1520-0477(1996)077<0437:TNYRP>2.0. $\mathrm{CO} ; 2$.

Lange, Stefan, 2019a. Trend-preserving bias adjustment and statistical downscaling with ISIMIP3BASD (v1.0). Geosci. Model Dev. 12, 3055-3070. https://doi.org/10.5194/ gmd-12-3055-2019.

Lange, S, 2019c. EartH2Observe, WFDEI and ERA-Interim data Merged and Biascorrected for ISIMIP (EWEMBI) [WWW Document. GFZ Data Serv. https://doi.org/ 10.5880/pik.2016.004.

Lange, Stefan, 2019b. WFDE5 over land merged with ERA5 over the ocean (W5E5). V. 1.0. [WWW Document]. GFZ Data Serv. https://doi.org/10.5880/pik.2019.023.

Lesk, C., Rowhani, P., Ramankutty, N., 2016. Influence of extreme weather disasters on global crop production. Nature 529, 84-87. https://doi.org/10.1038/nature16467.

Li, Y., Guan, K., Schnitkey, G.D., DeLucia, E., Peng, B., 2019. Excessive rainfall leads to maize yield loss of a comparable magnitude to extreme drought in the United States. Glob. Chang. Biol. 25 https://doi.org/10.1111/gcb.14628 gcb.14628.

Lobell, D.B., Schlenker, W., Costa-Roberts, J., 2011. Climate trends and global crop production since 1980. Science (80-.). https://doi.org/10.1126/science.1204531.

Lopez, J.R., Winter, J.M., Elliott, J., Ruane, A.C., Porter, C., Hoogenboom, G., 2017. Integrating growth stage deficit irrigation into a process based crop model. Agric. For. Meteorol. 243, 84-92. https://doi.org/10.1016/J.AGRFORMET.2017.05.001.

Lunt, T., Jones, A.W., Mulhern, W.S., Lezaks, D.P.M., Jahn, M.M., 2016. Vulnerabilities to agricultural production shocks: An extreme, plausible scenario for assessment of risk for the insurance sector. Clim. Risk Manag. 13, 1-9. https://doi.org/10.1016/j. crm.2016.05.001.

Martre, P., Wallach, D., Asseng, S., Ewert, F., Jones, J.W.J.W., Rötter, R.P.R.P., Boote, K. J.K.J., Ruane, A.C.A.C., Thorburn, P.J.P.J.P.J., Cammarano, D., Hatfield, J.L.J.L.J.L., Rosenzweig, C., Aggarwal, P.K.P.K.P.K., Angulo, C., Basso, B., Bertuzzi, P., Biernath, C., Brisson, N., Challinor, A.J.A.J.A.J., Doltra, J., Gayler, S., Goldberg, R., Grant, R.F.R.F.R.F., Heng, L., Hooker, J., Hunt, L.A.L.A.L.A., Ingwersen, J., Izaurralde, R.C.R.C., Kersebaum, K.C.K.C., Müller, C., Kumar, S.N.S.N., Nendel, C., O'leary, G., Olesen, J.E.J.E., Osborne, T.M.T.M., Palosuo, T., Priesack, E., Ripoche, D., Semenov, M.A.M.A.M.A., Shcherbak, I., Steduto, P., Stöckle, C.O.C.O.C. O., Stratonovitch, P., Streck, T., Supit, I., Tao, F., Travasso, M., Waha, K., White, J.W. J.W., Wolf, J., 2015. Multimodel ensembles of wheat growth: many models are better than one. Glob. Chang. Biol. 21 https://doi.org/10.1111/gcb.12768.

Mbow, C., Rosenzweig, C., Barioni, L.G., Benton, T.G., Herrero, M., Krishnapillai, M., Liwenga, E., Pradhan, P., Rivera-Ferre, M.G., Sapkota, T., Tubiello, F.N., Xu, Y., Contreras, E.M., Pereira, J.P., Blanchard, J., Fanzo, J., Frank, S., Kriewald, S., Lanigan, G., López, D., Mason-D'Croz, D., Neofotis, P., Pant, L., Rodrigues, R. Ruane, A.C., Waha, K., 2019. Food Security. In: Shukla, P.R., Skea, J., Buendia, E.C., Masson-Delmotte, V., Pörtner, H.-O., Roberts, D.C., Zhai, P., Slade, R., Connors, S., Diemen, R., van, Ferrat, M., Haughey, E., Luz, S., Neogi, S., Pathak, M., Petzold, J., Pereira, J.Portugal, Vyas, P., Huntley, E., Kissick, K., Belkacemi, M., Malley, J. (Eds.), Climate Change and Land: An IPCC Special Report on Climate Change, Desertification, Land Degradation. Sustainable Land Management, Food Security, and Greenhouse Gas Fluxes in Terrestrial Ecosystems.

McDermid, S.P., Ruane, A.C., Rosenzweig, C., Hudson, N.I., Morales, M.D., Agalawatte, P., Ahmad, S., Ahuja, L.R., Amien, I., Anapalli, S.S., Anothai, J., Asseng, S., Biggs, J., Bert, F., Bertuzzi, P., Bhatia, V.S., Bindi, M., Broad, I., Cammarano, D., Carretero, R., Chattha, A.A., Chung, U., Debats, S., Deligios, P., De Sanctis, G., Dhliwayo, T., Dumont, B., Estes, L., Ewert, F., Ferrise, R., Gaiser, T., Garcia, G., Gbegbelegbe, S., Geethalakshmi, V., Gerardeaux, E., Goldberg, R., Grant, B., Guevara, E., Hickman, J., Hoffmann, H., Huang, H., Hussain, J., Justino, F. B., Karunaratne, A.S., Koehler, A.-K., Kouakou, P.K., Kumar, S.N., Lakshmanan, A., Lieffering, M., Lin, X., Luo, Q., Magrin, G., Mancini, M., Marin, F.R., Marta, A.D., Masutomi, Y., Mavromatis, T., McLean, G., Meira, S., Mohanty, M., Moriondo, M., Nasim, W., Negm, L., Orlando, F., Orlandini, S., Ozturk, I., Soares Pinto, H.M., 
Podesta, G., Qi, Z., Ramarohetra, J., ur Rahman, M.H., Raynal, H., Rodriguez, G., Rötter, R., Sharda, V., Shuo, L., Smith, W., Snow, V., Soltani, A., Srinivas, K., Sultan, B., Swain, D.K., Tao, F., Tesfaye, K., Travasso, M.I., Trombi, G., Topaj, A., Vanuytrecht, E., Viscarra, F.E., Aftab Wajid, S., Wang, E., Wang, H., Wang, J., Wijekoon, E., Byun-Woo, L., Xiaoguang, Y., Young, B.H., Yun, J.I., Zhao, Z., Zubair, L., 2015. The AgMIP Coordinated Climate-Crop Modeling Project (C3MP): Methods and Protocols. In: Rosenzweig, C., Hillel, D. (Eds.), Handbook of Climate Change and Agroecosystems: The Agricultural Model Intercomparison and Improvement Project (AgMIP). Integrated Crop and Economic Assessments, Part 1. pp. 191-220. https://doi.org/10.1142/9781783265640_0008

Müller, C., Elliott, J., Chryssanthacopoulos, J., Arneth, A., Balkovic, J., Ciais, P., Deryng, D., Folberth, C., Glotter, M., Hoek, S., Iizumi, T., Izaurralde, R.C., Jones, C., Khabarov, N., Lawrence, P., Liu, W., Olin, S., Pugh, T.A.M., Ray, D.K., Reddy, A., Rosenzweig, C., Ruane, A.C., Sakurai, G., Schmid, E., Skalsky, R., Song, C.X., Wang, X., De Wit, A., Yang, H., 2017. Global gridded crop model evaluation: Benchmarking, skills, deficiencies and implications. Geosci. Model Dev. 10, 1403-1422. https://doi.org/10.5194/gmd-10-1403-2017.

Müller, C., Elliott, J., Kelly, D., Arneth, A., Balkovic, J., Ciais, P., Deryng, D., Folberth, C., Hoek, S., Izaurralde, R.C., Jones, C.D., Khabarov, N., Lawrence, P., Liu, W., Olin, S. Pugh, T.A.M., Reddy, A., Rosenzweig, C., Ruane, A.C., Sakurai, G., Schmid, E., Skalsky, R., Wang, X., de Wit, A., Yang, H., 2019. The Global Gridded Crop Model Intercomparison phase 1 simulation dataset. Sci. Data 6, 50. https://doi.org/ 10.1038/s41597-019-0023-8.

Nelson, G.C., van der Mensbrugghe, D., Ahammad, H., Blanc, E., Calvin, K., Hasegawa, T., Havlik, P., Heyhoe, E., Kyle, P., Lotze-Campen, H., von Lampe, M., Mason d'Croz, D., van Meijl, H., Müller, C., Reilly, J., Robertson, R., Sands, R.D., Schmitz, C., Tabeau, A., Takahashi, K., Valin, H., Willenbockel, D., 2014. Agriculture and climate change in global scenarios: why don't the models agree. Agric. Econ. 45, 85-101. https://doi.org/10.1111/agec.12091.

Onogi, K., Tsutsui, J., Koide, H., Sakamoto, M., Kobayashi, S., Hatsushika, H., Matsumoto, T., Yamazaki, N., Kamahori, H., Takahashi, K., Kadokura, S., Wada, K., Kato, K., Oyama, R., Ose, T., Mannoji, N., Taira, R., 2007. The JRA-25 reanalysis. J. Meteorol. Soc. Japan 85, 369-432. https://doi.org/10.2151/jmsj.85.369.

Parkes, B., Higginbottom, T.P., Hufkens, K., Ceballos, F., Kramer, B., Foster, T., 2019. Weather dataset choice introduces uncertainty to estimates of crop yield responses to climate variability and change. Environ. Res. Lett 14, 124089. https://doi.org/ 10.1088/1748-9326/ab5ebb.

Porter, J.R., Xie, L., Challinor, A.J., Cochrane, K., Howden, S.M., Iqbal, M.M., Lobell, D. B., Travasso, M.I., 2014. Food security and food production systems. In: Field, C.B., Barros, V.R., Dokken, D.J., Mach, K.J., Mastrandrea, M.D., Bilir, T.E., Chatterjee, M., Ebi, K.L., Estrada, Y.O., Genova, R.C., Girma, B., Kissel, E.S., Levy, A.N., MacCracken, S., Mastrandrea, P.R., White, L.L. (Eds.), Climate Change 2014: Impacts, Adaptation, and Vulnerability. Part A: Global and Sectoral Aspects. Contribution of Working Group II to the Fifth Assessment Report of the Intergovernmental Panel on Climate Change. https://doi.org/10.1111/j.17284457.2009.00312.x.

Porwollik, V., Müller, C., Elliott, J., Chryssanthacopoulos, J., Iizumi, T., Ray, D.K., Ruane, A.C., Arneth, A., Balkovič, J., Ciais, P., Deryng, D., Folberth, C., Izaurralde, R. C., Jones, C.D., Khabarov, N., Lawrence, P.J., Liu, W., Pugh, T.A.M., Reddy, A., Sakurai, G., Schmid, E., Wang, X., de Wit, A., Wu, X., 2017. Spatial and temporal uncertainty of crop yield aggregations. Eur. J. Agron. 88, 10-21. https://doi.org/ 10.1016/j.eja.2016.08.006.

Ray, D.K., Gerber, J.S., Macdonald, G.K., West, P.C., 2015. Climate variation explains a third of global crop yield variability. Nat. Commun. 6, 1-9. https://doi.org/ 10.1038 /ncomms6989.

Raymond, C., Horton, R.M., Zscheischler, J., Martius, O., AghaKouchak, A., Balch, J., Bowen, S.G., Camargo, S.J., Hess, J., Kornhuber, K., Oppenheimer, M., Ruane, A.C., Wahl, T., White, K., 2020. Understanding and Managing Connected Extreme Events. Nat. Clim. Chang.

Reichle, R.H., Koster, R.D., De Lannoy, G.J.M., Forman, B.A., Liu, Q., Mahanama, S.P.P., Toure, A., 2011. Assessment and enhancement of MERRA land surface hydrology estimates. J. Clim. 24, 6322-6338. https://doi.org/10.1175/JCLI-D-10-05033.1.

Rienecker, M.M., Suarez, M.J., Gelaro, R., Todling, R., Bacmeister, J., Liu, E., Bosilovich, M.G., Schubert, S.D., Takacs, L., Kim, G.K., Bloom, S., Chen, J., Collins, D., Conaty, A., Da Silva, A., Gu, W., Joiner, J., Koster, R.D., Lucchesi, R., Molod, A., Owens, T., Pawson, S., Pegion, P., Redder, C.R., Reichle, R., Robertson, F. R., Ruddick, A.G., Sienkiewicz, M., Woollen, J., 2011. MERRA: NASA's modern-era retrospective analysis for research and applications. J. Clim. 24, 3624-3648. https:// doi.org/10.1175/JCLI-D-11-00015.1.

Rosenzweig, C., Elliott, J., Deryng, D., Ruane, A.C.A.C., Müller, C., Arneth, A., Boote, K.J. K.J., Folberth, C., Glotter, M., Khabarov, N., Neumann, K., Piontek, F., Pugh, T.A.M. T.A.M., Schmid, E., Stehfest, E., Yang, H., Jones, J.W.J.W., 2014. Assessing agricultural risks of climate change in the 21st century in a global gridded crop model intercomparison. Proc. Natl. Acad. Sci. U. S. A. 111, 3268-3273. https://doi org/10.1073/pnas.1222463110.

Rosenzweig, C., Jones, J.W., Hatfield, J.L., Ruane, A.C., Boote, K.J., Thorburn, P., Antle, J.M., Nelson, G.C., Porter, C., Janssen, S., Asseng, S., Basso, B., Ewert, F., Wallach, D., Baigorria, G., Winter, J.M., 2013. The Agricultural Model Intercomparison and Improvement Project (AgMIP): Protocols and pilot studies. Agric. For. Meteorol. 170, 166-182. https://doi.org/10.1016/j. agrformet.2012.09.011.

Ruane, Alex C, Antle, J., Elliott, J., Folberth, C., Hoogenboom, G., Croz, D.M., Müller, C., Porter, C., Phillips, M.M., Raymundo, R.M., Sands, R., Valdivia, R.O., White, J.W., Wiebe, K., Rosenzweig, C., 2018b. Biophysical and economic implications for agriculture of $+1.5^{\circ}$ and $+2.0^{\circ} \mathrm{C}$ global warming using AgMIP Coordinated Global and Regional Assessments. Clim. Res. 76, 17-39.
Ruane, Alex C., Goldberg, R., Chryssanthacopoulos, J., 2015b. Climate forcing datasets for agricultural modeling: Merged products for gap-filling and historical climate series estimation. Agric. For. Meteorol. 200, 233-248. https://doi.org/10.1016/j. agrformet.2014.09.016.

Ruane, A.C., Hudson, N.I., Asseng, S., Camarrano, D., Ewert, F., Martre, P., Boote, K.J., Thorburn, P.J., Aggarwal, P.K., Angulo, C., Basso, B., Bertuzzi, P., Biernath, C., Brisson, N., Challinor, A.J., Doltra, J., Gayler, S., Goldberg, R., Grant, R.F., Heng, L., Hooker, J., Hunt, L.A., Ingwersen, J., Izaurralde, R.C., Kersebaum, K.C., Kumar, S.N., Müller, C., Nendel, C., O'Leary, G., Olesen, J.E., Osborne, T.M., Palosuo, T. Priesack, E., Ripoche, D., Rötter, R.P., Semenov, M.A., Shcherbak, I., Steduto, P., Stöckle, C.O., Stratonovitch, P., Streck, T., Supit, I., Tao, F., Travasso, M., Waha, K., Wallach, D., White, J.W., Wolf, J., 2016. Multi-wheat-model ensemble responses to interannual climate variability. Environ. Model. Softw. 81, 86-101. https://doi.org/ 10.1016/j.envsoft.2016.03.008.

Ruane, Alex C., Phillips, M.M., Rosenzweig, C., 2018a. Climate shifts within major agricultural seasons for +1.5 and $+2.0^{\circ} \mathrm{C}$ worlds: HAPPI projections and AgMIP modeling scenarios. Agric. For. Meteorol. 259, 329-344. https://doi.org/10.1016/j. agrformet.2018.05.013.

Ruane, A.C., Rosenzweig, C., Asseng, S., Boote, K.J., Elliott, J., Ewert, F., Jones, J.W., Martre, P., McDermid, S.P., Müller, C., Snyder, A., Thorburn, P.J., 2017. An AgMIP framework for improved agricultural representation in integrated assessment models. Environ. Res. Lett. 12 https://doi.org/10.1088/1748-9326/aa8da6.

Ruane, Alexander C., Winter, J.M., McDermid, S.P., Hudson, N.I., 2015a. AgMIP Climate Data and Scenarios for Integrated Assessment. In: Rosenzweig, C., Hillel, D. (Eds.), Handbook of Climate Change and Agroecosystems: The Agricultural Model Intercomparison and Improvement Project (AgMIP). Integrated Crop and Economic Assessments, Part 1, pp. 45-78. https://doi.org/10.1142/9781783265640 0003.

Rudolf, B., Becker, A., Schneider, U., Meyer-Christoffer, A., Ziese, M., 2010. GPCC Status Report December 2010 (On the most recent gridded global data set issued in fall 2010 by the Global Precipitation Climatology Centre (GPCC)). DWD/GPCC.

Saha, S., Moorthi, S., Pan, H.-L., Wu, X., Wang, Jie, Nadiga, S., Tripp, P., Kistler, R., Woollen, J., Behringer, D., Liu, H., Stokes, D., Grumbine, R., Gayno, G., Wang, Jun, Hou, Y.-T., Chuang, H.-Y., Juang, H.-M.H., Sela, J., Iredell, M., Treadon, R., Kleist, D., Van Delst, P., Keyser, D., Derber, J., Ek, M., Meng, J., Wei, H., Yang, R., Lord, S., van den Dool, H., Kumar, A., Wang, W., Long, C., Chelliah, M., Xue, Y., Huang, B., Schemm, J.-K., Ebisuzaki, W., Lin, R., Xie, P., Chen, M., Zhou, S., Higgins, W., Zou, C.-Z., Liu, Q., Chen, Y., Han, Y., Cucurull, L., Reynolds, R.W., Rutledge, G., Goldberg, M., 2010. NCEP Climate Forecast System Reanalysis (CFSR) 6-hourly Products, January 1979 to December 2010. 10.5065/D69K487J.

Savary, S., Willocquet, L., Pethybridge, S.J., Esker, P., McRoberts, N., Nelson, A., 2019. The global burden of pathogens and pests on major food crops. Nat. Ecol. Evol. 3 , 430-439. https://doi.org/10.1038/s41559-018-0793-y.

Schauberger, B., Gornott, C., Wechsung, F., 2017. Global evaluation of a semiempirical model for yield anomalies and application to within-season yield forecasting. Glob. Chang. Biol. 23, 4750-4764. https://doi.org/10.1111/gcb.13738.

Schewe, J., Gosling, S.N., Reyer, C., Zhao, F., Ciais, P., Elliott, J., Francois, L., Huber, V., Lotze, H.K., Seneviratne, S.I., van Vliet, M.T.H., Vautard, R., Wada, Y., Breuer, L., Büchner, M., Carozza, D.A., Chang, J., Coll, M., Deryng, D., de Wit, A., Eddy, T.D., Folberth, C., Frieler, K., Friend, A.D., Gerten, D., Gudmundsson, L., Hanasaki, N., Ito, A., Khabarov, N., Kim, H., Lawrence, P., Morfopoulos, C., Müller, C., Müller Schmied, H., Orth, R., Ostberg, S., Pokhrel, Y., Pugh, T.A.M., Sakurai, G., Satoh, Y., Schmid, E., Stacke, T., Steenbeek, J., Steinkamp, J., Tang, Q., Tian, H., Tittensor, D. P., Volkholz, J., Wang, X., Warszawski, L., 2019. State-of-the-art global models underestimate impacts from climate extremes. Nat. Commun. 10, 1-14. https://doi. org/10.1038/s41467-019-08745-6.

Schollaert Uz, S., Ruane, A.C., Duncan, B.N., Compton, Tucker, J., Huffman, G.J., Mladenova, I.E., Osmanoglu, B., Holmes, T.R.H., Mcnally, A., Peters-Lidard, C. Bolten, J.D., Das, N., Rodell, M., Mccartney, S., Anderson, M.C., Doorn, B., 2019. Earth observations and integrative models in support of food and water security. Remote Sens. Earth Syst. Sci. https://doi.org/10.1007/s41976-019-0008-6.

Sheffield, J., Goteti, G., Wood, E.F., 2006. Development of a 50-Year High-Resolution Global Dataset of Meteorological Forcings for Land Surface Modeling. J. Clim. 19, 3088-3111. https://doi.org/10.1175/JCLI3790.1.

Snyder, A., Calvin, K.V., Phillips, M., Ruane, A.C., 2019. A crop yield change emulator for use in GCAM and similar models: Persephone v1.0. Geosci. Model Dev. 12 1319-1350. https://doi.org/10.5194/gmd-12-1319-2019.

Stackhouse Jr, P.W., Gupta, S.K., Cox, S.J., Zhang, T., Mikovitz, J.C., Hinkelman, L.M. 2011. The NASA/GEWEX surface radiation budget release 3.0: 24.5-year dataset. Gewex news 21, 10-12.

Thoning, K.W., Tans, P.P., Komhyr, W.D., 1989. Atmospheric carbon dioxide at Mauna Loa Observatory: 2. Analysis of the NOAA GMCC data, 1974-1985. J. Geophys. Res. Atmos. 94, 8549-8565. https://doi.org/10.1029/JD094iD06p08549.

Toreti, A., Maiorano, A., De Sanctis, G., Webber, H., Ruane, A.C., Fumagalli, D., Ceglar, A., Niemeyer, S., Zampieri, M., 2019. Using reanalysis in crop monitoring and forecasting systems. Agric. Syst. 168, 144-153. https://doi.org/10.1016/j. agsy.2018.07.001.

UNISDR, 2015. Sendai Framework for Disaster Risk Reduction 2015-2030.

United Nations, 2015a. Adoption of the Paris Agreement. In: Conference of the Parties on Its Twenty-First Session.

United Nations, 2015b. Transforming our world: The 2030 Agenda for Sustainable Development [WWW Document]. United Nations. URL http://www.un.org/ga/se arch/view_doc.asp? symbol=A/RES/70/1\&Lang=E.

Uppala, S.M., Kållberg, P.W., Simmons, A.J., Andrae, U., da Costa Bechtold, V., Fiorino, M., Gibson, J.K., Haseler, J., Hernandez, A., Kelly, G.A., Li, X., Onogi, K., Saarinen, S., Sokka, N., Allan, R.P., Andersson, E., Arpe, K., Balmaseda, M.A., Beljaars, A.C.M., van de Berg, L., Bidlot, J., Bormann, N., Caires, S., Chevallier, F. 
Dethof, A., Dragosavac, M., Fisher, M., Fuentes, M., Hagemann, S., Hólm, E. Hoskins, B.J., Isaksen, L., Janssen, P.A.E.M., Jenne, R., McNally, A.P., Mahfouf, J.F., Morcrette, J.J., Rayner, N.A., Saunders, R.W., Simon, P., Sterl, A., Trenberth, K.E., Untch, A., Vasiljevic, D., Viterbo, P., Woollen, J., 2005. The ERA-40 re-analysis. Q. J. R. Meteorol. Soc. https://doi.org/10.1256/aj.04.176.

Valdivia, R.O., Antle, J.M., Rosenzweig, C., Ruane, A.C., Vervoort, J., Ashfaq, M., Hathie, I., Tui, S.H.-K., Mulwa, R., Nhemachena, C., Ponnusamy, P., Rasnayaka, H., Singh, H., 2015. Representative Agricultural Pathways and Scenarios for Regional Integrated Assessment of Climate Change Impacts, Vulnerability, and Adaptation. In: Rosenzweig, C., Hillel, D. (Eds.), Handbook of Climate Change and Agroecosystems: The Agricultural Model Intercomparison and Improvement Project (AgMIP). Integrated Crop and Economic Assessments, Part 1, pp. 101-145. https://doi.org/ 10.1142/9781783265640_0005.

van Bussel, L.G.J., Grassini, P., van Wart, J., Wolf, J., Claessens, L., Yang, H., Boogaard, H., de Groot, H., Saito, K., Cassman, K.G., van Ittersum, M.K., 2015. From field to atlas: Upscaling of location-specific yield gap estimates. F. Crop. Res. 177, 98-108. https://doi.org/10.1016/j.fcr.2015.03.005.

van Ittersum, M.K., van Bussel, L.G.J., Wolf, J., Grassini, P., van Wart, J., Guilpart, N., Claessens, L., De Groot, H., Wiebe, K., Mason-D'Croz, D., Yang, H., Boogaard, H., Van Oort, P.A.J., Van Loon, M.P., Saito, K., Adimo, O., Adjei-Nsiah, S., Agali, A., Bala, A., Chikowo, R., Kaizzi, K., Kouressy, M., Makoi, J.H.J.R., Ouattara, K., Tesfaye, K., Cassman, K.G., 2016. Can sub-Saharan Africa feed itself? Proc. Natl. Acad. Sci. U. S. A. 113, 14964-14969. https://doi.org/10.1073/pnas.1610359113.

Wallach, D., Mearns, L.O., Rivington, M., Antle, J.M., Ruane, A.C., 2015. Uncertainty in Agricultural Impact Assessment, in: Rosenzweig, C., Hillel, D. (Eds.), Handbook of
Climate Change and Agroecosystems: The Agricultural Model Intercomparison and Improvement Project (AgMIP) Integrated Crop and Economic Assessments, Part 1. pp. 223-259. 10.1142/9781783265640_0009.

Wallach, D., Mearns, L.O., Ruane, A.C., Rötter, R.P., Asseng, S., 2016. Lessons from climate modeling on the design and use of ensembles for crop modeling. Clim. Change 139, 551-564. https://doi.org/10.1007/s10584-016-1803-1.

Weedon, G.P., Balsamo, G., Bellouin, N., Gomes, S., Best, M.J., Viterbo, P., 2018. The WFDEI Meteorological Forcing Data. https://doi.org/10.5065/486N-8109.

Weedon, G.P., Gomes, S., Viterbo, P., Shuttleworth, W.J., Blyth, E., ÖSterle, H., Adam, J. C., Bellouin, N., Boucher, O., Best, M., 2011. Creation of the WATCH Forcing Data and Its Use to Assess Global and Regional Reference Crop Evaporation over Land during the Twentieth Century. J. Hydrometeorol. 12, 823-848. https://doi.org/ 10.1175/2011JHM1369.1.

Willmott, C.J., Matsuura, K., 1995. Smart Interpolation of Annually Averaged Air Temperature in the United States. J. Appl. Meteorol. 34, 2577-2586.doi:10.1175/ 1520-0450(1995)034<2577:SIOAAA >2.0.CO;2.

You, L., Wood-Sichra, U., Fritz, S., Guo, Z., See, L., Koo, J., 2014. Spatial Production Allocation Model (SPAM) 2005 v2.0. MapSPAM [WWW Document]. URL http:// mapspam.info.

Zhao, C., Liu, B., Piao, S., Wang, X., Lobell, D.B., Huang, Y., Huang, M., Yao, Y., Bassu, S., Ciais, P., Durand, J.-L., Elliott, J., Ewert, F., Janssens, I.A., Li, T., Lin, E., Liu, Q., Martre, P., Müller, C., Peng, S., Peñuelas, J., Ruane, A.C., Wallach, D., Wang, T., Wu, D., Liu, Z., Zhu, Y., Zhu, Z., Asseng, S., 2017. Temperature increase reduces global yields of major crops in four independent estimates. Proc. Natl. Acad. Sci. https://doi.org/10.1073/pnas.1701762114, 201701762. 